\title{
Bioactive Synthetic Peptides for Oral Tissues Regeneration
}

\begin{abstract}
Mercedes Bermúdez ${ }^{1 * t}$, Lía $\mathrm{Hoz}^{2 \dagger}$, Gonzalo Montoya ${ }^{2 \dagger}$, Mikado Nidome ${ }^{2}$, Adriana Pérez-Soria ${ }^{2+}$, Enrique Romo ${ }^{2 t}$, Uriel Soto-Barreras ${ }^{3 t}$, Julio Garnica-Palazuelos ${ }^{4}$, Maribel Aguilar-Medina ${ }^{1}$, Rosalío Ramos-Payán ${ }^{1}$ and Carlos Villegas-Mercado ${ }^{4 \star t}$
\end{abstract}

\begin{abstract}
${ }^{1}$ Facultad de Ciencias Químico Biológicas, Universidad Autónoma de Sinaloa, Culiacán, Mexico, ${ }^{2}$ Facultad de Odontología, Universidad Nacional Autónoma de México, CDMX, Mexico, ${ }^{3}$ Facultad de Odontología, Universidad Autónoma de Chihuahua, Chihuahua, Mexico, ' Facultad de Odontología, Universidad Autónoma de Sinaloa, Culiacán, Mexico
\end{abstract}

\section{OPEN ACCESS}

Edited by:

Fabricio Mezzomo Collares, Federal University of Rio Grande do Sul, Brazil

Reviewed by:

Vivian Petersen Wagner, The University of Sheffield,

United Kingdom

Fernanda Visioli,

Federal University of Rio Grande do Sul, Brazil

*Correspondence:

Mercedes Bermúdez bermudezcm@uas.edu.mx

Carlos Villegas-Mercado

carlosvillegas@uas.edu.mx

${ }^{+}$These authors have contributed equally to this work

Specialty section: This article was submitted to Biomaterials,

a section of the journal

Frontiers in Materials

Received: 19 January 2021

Accepted: 17 February 2021

Published: 23 April 2021

Citation:

Bermúdez M, Hoz L, Montoya G. Nidome M, Pérez-Soria A, Romo E,

Soto-Barreras $U$

Garnica-Palazuelos J,

Aguilar-Medina M, Ramos-Payán R and Villegas-Mercado $C$ (2021) Bioactive Synthetic Peptides for Oral

Tissues Regeneration.

Front. Mater. 8:655495.

doi: 10.3389/fmats.2021.655495
Regenerative therapy in oral tissues has gained relevance since tissue loss due to congenital or acquired diseases as well as trauma is a major health problem worldwide. Regeneration depends on the natural capacity of the body and the use of biomaterials and bioactive molecules that can module the processes to replace lost or damaged tissues and restore function. The combined use of scaffolds, cells, and bioactive molecules such as peptides is considered the best approach to achieve tissue regeneration. These peptides can induce diverse cellular processes as they can influence cell behavior and also can modify scaffold properties, giving as a result the enhancement of cell adhesion, proliferation, migration, differentiation, and biomineralization that are required given the complex nature of oral tissues. Specifically, synthetic peptides (SP) have a positive influence on scaffold biocompatibility since in many cases they can mimic the function of a natural peptide or a full-length protein. Besides, they are bioactive molecules easy to produce, process, and modify, and they can be prepared under well-defined and controlled conditions. This review aims to compile the most relevant information regarding advances in SP for dental and periodontal tissue regeneration, their biological effects, and their clinical implications. Even though most of the SP are still under investigation, some of them have been studied in vitro and in vivo with promising results that may lead to preclinical studies. Besides there are SP that have shown their efficacy in clinical trials such as P11-4 for enamel regeneration or caries prevention and ABM/P-15 for cementum, periodontal ligament (PDL), and alveolar bone on a previously calculus- and biofilm-contaminated zone. Also, some SP are commercially available such as PTH1-34 and PepGen P-15 which are used for bone defects treatment.

Keywords: synthetic peptide, oral tissue, periodontal regeneration, dental materials, bioactive peptides, dental regeneration

\section{INTRODUCTION}

A peptide can be defined as a short polymer of amino acids. Depending on the definition of different authors, sizes can vary from $<20,<50$, to $<100$ (Lien and Lowman, 2003; Sato et al., 2006; Vlieghe et al., 2010; Hamley, 2017). In the last decades, more than 7,000 native peptides (NP) with important human physiological functions have been studied (Fosgerau and Hoffmann, 2015) since they have 
roles as cell adhesion motifs, structural peptides, cell-penetrating, and tumor-homing peptides, antimicrobial peptides, peptide hormones, growth factors, and matrix metalloprotease substrates, amyloid peptides, neuropeptides, peptide tags, and other miscellaneous NP (Hamley, 2017). However, NP are often not directly suitable for therapeutic use because they have intrinsic weaknesses, like poor chemical and physical stability, short circulating plasma half-life, low oral bioavailability, and rapid removal from the circulation by the liver and kidneys (Vlieghe et al., 2010; Fosgerau and Hoffmann, 2015; Erak et al., 2018; Lau and Dunn, 2018).

The use of peptides for human therapeutic began with peptides such as insulin and adrenocorticotrophic hormone (ACTH) isolated from natural sources in the first half of the 20th century (Banting et al., 1922). Further, with sequence elucidation and chemical synthesis of peptides in the 1950s, synthetic oxytocin and vasopressin entered to clinical use (Stürmer, 1989).

In recent years the pharmaceutical industry has increased attention to new therapeutic peptides, constantly reaching clinical application (Vlieghe et al., 2010; Dang and Süssmuth, 2017). By 2018 more than 60 peptides were approved by the FDA and more than 600 were in clinical and preclinical trials (Vlieghe et al., 2010; Erak et al., 2018). The production of therapeutic synthetic peptides (SP) has become possible with recent developments of solid-phase peptide synthesis (Vlieghe et al., 2010) and novel synthetic strategies allow the modulation of pharmacokinetic properties and target specificity through amino acid, backbone modification, incorporation of non-natural amino acids, and peptide conjugates (Conjugation to polyethylene glycol (PEG), lipids, and proteins such as $\mathrm{Fc}$ fragments) extending the half-life or improving solubility (Sato et al., 2006; Fosgerau and Hoffmann, 2015; Lau and Dunn, 2018).

Based on their chemistry, SP are categorized concerning their relationship to NP molecules: native, analog, and heterologous. A native has the same sequence as an NP product, analogs are defined as modified or substituted versions of NP with improved drug properties, and heterologous peptides were discovered independently of the natural peptide through synthetic library screening, phage display, or other methods (Sato et al., 2006; Vlieghe et al., 2010; Hamley, 2017; Lau and Dunn, 2018).

As potential therapeutics SP offer several advantages over other molecules: increased specificity, small size (increasing their potential to penetrate further into tissues) (Sato et al., 2006), excellent safety, tolerability, and efficacy profiles in humans (Fosgerau and Hoffmann, 2015). SP also have lower cost and production complexity compared with protein-based biopharmaceuticals (Fosgerau and Hoffmann, 2015). They are generally less immunogenic than recombinant proteins and antibodies, show higher activity per unit mass, and have greater stability (can be stored at room temperature for a long time). Additionally, degradation products of peptides are amino acids, and given their short half-life, few peptides accumulate in tissues, minimizing the risks of complications caused by their metabolites and the risks of systemic toxicity (Vlieghe et al., 2010).
Oral tissue regeneration is crucial since their congenital or acquired loss by trauma or diseases is a major health problem (Abou Neel et al., 2014). In this regard, the healing capacity of the body and the use of bioactive molecules able to module the processes to replace lost tissue and restore function are key. The best approach to achieve tissue regeneration is the combined use of scaffolds, cells, and bioactive molecules such as SP which can induce diverse cellular processes as they can influence cell behavior and also can modify scaffold properties. SP enhance cell adhesion, proliferation, migration, differentiation, and biomineralization that are required given the complex nature of oral tissues. Therefore, the purpose of this review is to discuss recently developed advances regarding SP for dental and periodontal tissue regeneration. Our goal is to highlight the current approaches in their applications to demonstrate their potential and at the same time to draw attention to the advances and the issues which need to be addressed for progressing in oral tissues enginnering.

\section{DENTAL TISSUE REGENERATION}

Dental caries remains the most common disease worldwide, and it is defined as pathophysiological processes in the dental biofilm that cause an imbalance in the demineralization-remineralization equilibrium, leading to a net loss of tooth minerals progressing to a cavity. This process begins by dissolution of the subsurface mineral tooth structure knowing like white spot, followed by progression to irreversible cavitation of the mineralized surface layer (Han et al., 2017; Jablonski-Momeni et al., 2019; Pandya and Diekwisch, 2019).

When a tooth is damaged by caries, the enamel and dentin are degraded by enzymes and acids from microorganisms. In this situation, the odontoblast layer in the pulp chamber releases bioactive molecules with reparative potential for dentinogenesis. However, the exact mechanism that regulates this process is unclear and dentin regeneration remains a great challenge in the clinic (Smith et al., 1995; Bleicher, 2014; Wang et al., 2014).

Additionally, after caries occur, the clinical intervention is focused on removing the infection, preserving as much natural tooth structure as possible to use adhesive restorative materials to replace the lost enamel and dentin. In the case of the pulp chamber exposition, the direct capping with calcium hydroxide $\left(\mathrm{CaOH}_{2}\right)$ and/or mineral trioxide aggregate (MTA) is the only clinical treatment option focused on the preservation of pulp vitality by the formation of reactionary dentin (tertiary dentin) (Huang, 2011; Hilton et al., 2013). Although these treatments have, in some cases, success rates (60-80\%), nowadays, there is not an effective treatment in the clinical area to induce cellular repair of the enamel, dentin, and pulp. SP (Figure 1) have emerged as an alternative for the regeneration of dental organ tissues (Table 1).

\section{Enamel}

Dental enamel is a calcified tissue that forms the outer protective covering of the anatomical crown of a tooth and is produced by ameloblasts. However, these enamel-forming cells, as well as the enamel organ stem cells are lost at the time of tooth eruption. 


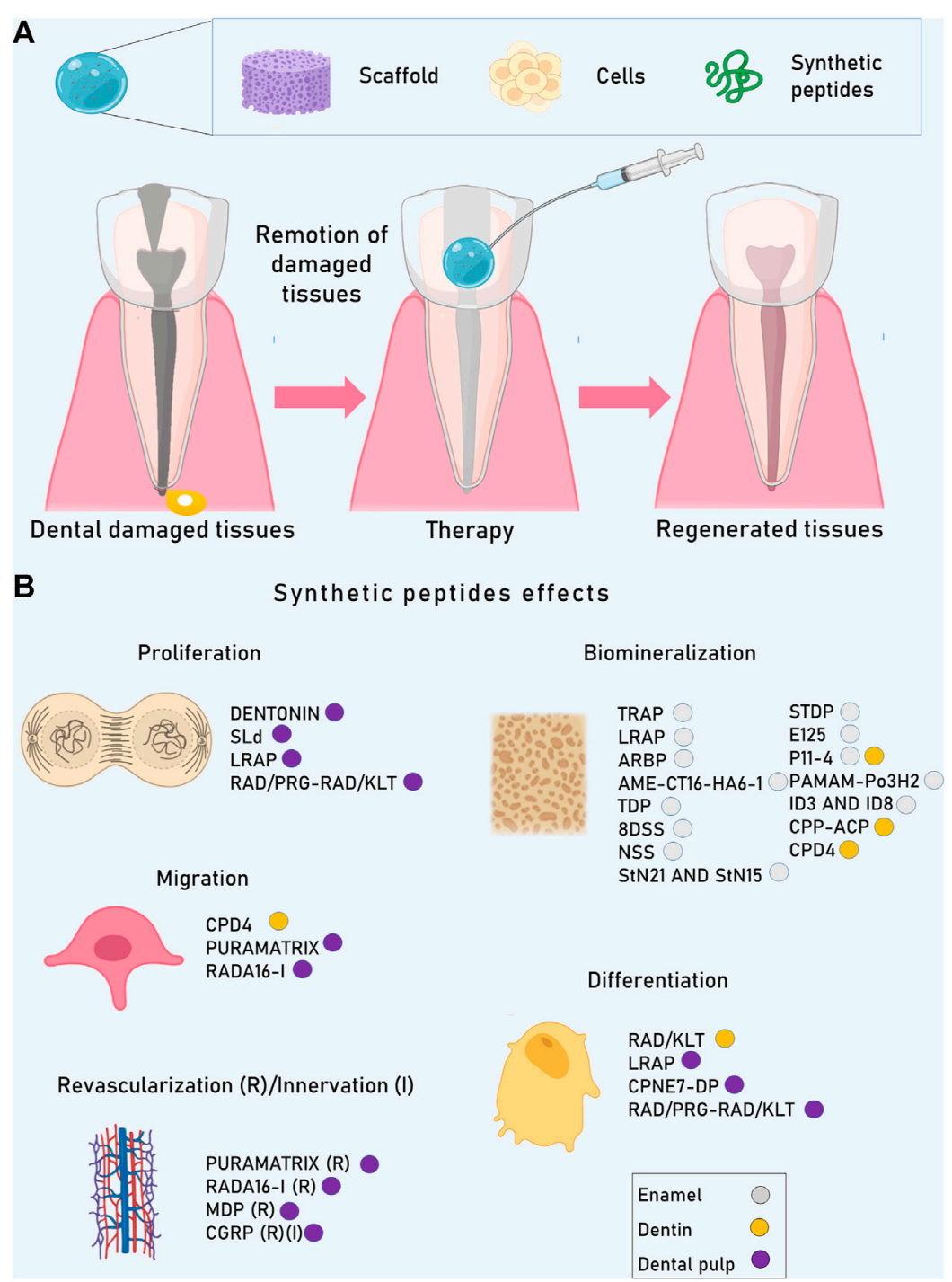

FIGURE 1 | The combined use of scaffolds, cells, and bioactive molecules such as SP is considered the best approach to achieve tissue regeneration. (A) Dental organs can be damaged principally by caries. Depending on the damage level, enamel, dentin or even pulp can be injured. Advances in the field of SP could be beneficial to treat and regenerate lost tissues. (B) SP can induce diverse cellular processes in dental tissues as they can influence cell behavior and also can modify scaffold properties, giving as a result the enhancement of cell proliferation, migration, revascularizatión, innervation, differentiation, and biomineralization.

Mature enamel is mainly composed of inorganic material (96\%) formed by crystals of hydroxyapatite (HA) and a small proportion of water $(3 \%)$ and proteins (1\%) that bind the mineralized fibers together (Hara and Zero, 2010; Pandya and Diekwisch, 2019). Also, more than 40 trace elements have been identified in enamel, which can be incorporated in various ways: ion exchange in the hydration shell, which is the layer of water adjacent to the crystal; direct absorption on the surface of the crystal; and substitution with components of the crystal of similar size and charge. The acid solubility of a tooth and thus its caries resistance can be affected by the crystal size and shape, and the proximity of the crystals (Hara and Zero, 2010; Kind et al., 2017; González-Cabezas and Fernández, 2018; Dissanayake et al., 2020; Farooq and Bugshan, 2020).

\section{Peptides Derived from the Amino Acid Sequence of Enamel and Dentin Proteins}

Peptides derived from enamel and dentin proteins have been developed to prevent demineralization and/or promote the remineralization process (Chung and Huang, 2013; Yang et al., 2016; Buzalaf et al., 2017). For instance, amelogenin is an important protein involved in the growth and maturation of enamel crystals in the newly formed enamel matrix and is absent in mature enamel (Buzalaf et al., 2017; Farooq and Bugshan, 2020). This protein has been used to form chitosan-amelogenin hydrogel (CS-AMEL) to promotes enamel remineralization. As a result of proteolysis of amelogenin by matrix metalloproteinase 20 (MMP-20) during the biomimetic enamel regrowth, the newly 
TABLE 1 | Synthetic peptides used for dental tissue regeneration.

\section{ENAMEL
ENABLE1}

Peptide Methodology

\begin{tabular}{ll} 
Peptide & Methodology \\
\hline Amelogenin peptide (TRAP)/(LRAP) & In vitro study with samples from bovine
\end{tabular}
enamel and human molars Artificial lesion: 30\% phosphoric acid for $10 \mathrm{~s}$. Remineralization: Artificial saliva for either 5 or 10 days at $37^{\circ} \mathrm{C}$

Amelogenin repeat-based peptide In vitro study in bovine permanent incisors. consisting of 22-residues in five tandem Artificial lesions: $50 \mathrm{mM}$ acetic acid $(\mathrm{pH} 4.5)$,

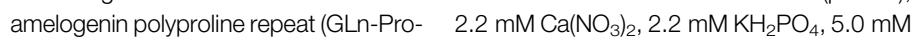
$\mathrm{X}$ ) and a seven residues hydrophilic tail $\quad \mathrm{NaN}_{3}$, and $0.5 \mathrm{ppm} \mathrm{NaF}$; at $37^{\circ} \mathrm{C}$ for 3 days Remineralization: 12 days at $37^{\circ} \mathrm{C} \mathrm{pH}$ cycling model. Remineralization solution: $20 \mathrm{mM}$ HEPES (pH 7.0), $0.9 \mathrm{mM} \mathrm{KH}_{2} \mathrm{PO}_{4}, 1.5 \mathrm{mM}$ $\mathrm{CaCl}_{2}, 130 \mathrm{mM} \mathrm{KCl}, 1.0 \mathrm{mM} \mathrm{NaN}_{3}$ for $22 \mathrm{~h}$ In vivo study in rat caries model using the sprague-dawley rat model of early enamel lesions induced by $S$. mutans

Ame-CT16-HA6-1 (16 carboxyl-terminal In vitro study in human un-erupted third residues of amelogenin join to a sequence of SVSVG-MKSPRR denominated HA6-1) molars Artificial lesions: 37\% phosphoric acid for $30 \mathrm{~s}$ Remineralization: Simulated saliva (1.5 mM $\mathrm{Ca}^{2+}, 0.9 \mathrm{mM} \mathrm{HPO}_{4}$, and HEPES) for 7 days Tufteline derived peptide (TDP)

DPP-derived peptide: (8DSS)

NSS peptide (an aspartate is replaced for asparagine from DSS sequence of DPP) In vitro study in human third molars Artificial lesions: $50 \mathrm{mM}$ acetic acid ( $\mathrm{pH} 4.5)$, $2.2 \mathrm{mM} \mathrm{Ca}\left(\mathrm{NO}_{3}\right)_{2}, 2.2 \mathrm{mM} \mathrm{KH}_{2} \mathrm{PO}_{4}, 5.0 \mathrm{mM}$ $\mathrm{NaN}_{3}$, and $0.5 \mathrm{ppm} \mathrm{NaF}$ at $37^{\circ} \mathrm{C}$ for 3 days Remineralization: 12 days $\mathrm{pH}$ cycling model remineralization solution: $20 \mathrm{mM}$ HEPES $(\mathrm{pH}$ 7.0), $0.9 \mathrm{mM} \mathrm{KH}_{2} \mathrm{PO}_{4}, 1.5 \mathrm{mM} \mathrm{CaCl}_{2}$, $130 \mathrm{mM} \mathrm{KCl}$, and $1.0 \mathrm{mM} \mathrm{NaN}_{3}$ for $22 \mathrm{~h}$ In vitro study in bovine permanent incisors. Artificial lesions: $50 \mathrm{mM}$ acetic acid ( $\mathrm{pH} 4.5)$, $2.2 \mathrm{mM} \mathrm{Ca}\left(\mathrm{NO}_{3}\right)_{2}, 2.2 \mathrm{mM} \mathrm{KH}_{2} \mathrm{PO}_{4}, 5.0 \mathrm{mM}$ $\mathrm{NaN}_{3}$ and $0.5 \mathrm{ppm} \mathrm{NaF}$ at $37^{\circ} \mathrm{C}$ for 3 days and low-speed magnetic stirring (100 rpm). Remineralization: 12 days of $\mathrm{pH}$ cycling model remineralization solution: $20 \mathrm{mM}$ HEPES (pH 7.0), $1.5 \mathrm{mM} \mathrm{CaCl}_{2}, 0.9 \mathrm{mM}$ $\mathrm{KH}_{2} \mathrm{PO}_{4}, 130 \mathrm{mM} \mathrm{KCl}, 1.0 \mathrm{mM} \mathrm{NaN}_{3}$ for $23 \mathrm{~h}$

In vivo study in rat caries model using the sprague-dawley rat model of early enamel lesions induced by $S$. mutans

In vitro study in human third molars

Artificial lesions: $1 \mathrm{M}$ citric acid $(\mathrm{pH} 2)$ for

2 min. Remineralization: Artificial saliva (6.84 mM NaCl, 5.37 mM KCl, $5.44 \mathrm{mM}$ $\mathrm{CaCl}_{2}-2 \mathrm{H}_{2} \mathrm{O}, 4.42 \mathrm{mM} \mathrm{NaH}_{2} \mathrm{PO}_{4}-2 \mathrm{H}_{2} \mathrm{O}$, $0.21 \mathrm{mM} \mathrm{Na}_{2} \mathrm{~S}-9 \mathrm{H}_{2} \mathrm{O}$ and $16.65 \mathrm{mM}$ urea) at $37^{\circ} \mathrm{C}$ for 14 days

StN21 and StN15 In vitro study in porous HA blocks Artificial lesions: $0.1 \mathrm{M}$ acetic acid at $\mathrm{pH} 4$ for 120 h. Modified buffer $(100 \mathrm{mM} \mathrm{NaCl}$, $40 \mathrm{mM} \mathrm{KCl}, 4.3 \mathrm{mM} \mathrm{Na}_{2} \mathrm{HPO}_{4}$, and $1.4 \mathrm{mM}$ $\left.\mathrm{KH}_{2} \mathrm{PO}_{4}\right) \mathrm{pH} 7.39$ for $120 \mathrm{~h}$

Statherin-derived peptide (DpSpSEEKC) In vitro study in human premolars Artificial lesions: $37 \%$ phosphoric acid for $45 \mathrm{~s}$. Remineralization: Artificial saliva (1.5 mM CaCl $2,0.9 \mathrm{mM} \mathrm{KH}_{2} \mathrm{PO}_{4}, 130 \mathrm{mM}$ $\mathrm{KCl}, 1 \mathrm{mM} \mathrm{NaN}_{3}$, and $20 \mathrm{mM} \mathrm{HEPES}$ ) at $37^{\circ} \mathrm{C}$ for $12 \mathrm{~h}$
Promotes enamel crystal nucleation and growth. Improves remineralization of enamel surface lesions

References

Han et al. (2017); Dissanayake et al. (2020); Farooq and Bugshan (2020); Wang et al. (2020)

Promotes the remineralization of enamel caries. Bind on the enamel surface, can stabilize amorphous calcium phosphate (ACP), it can control the crystallization of hydroxyapatite $(\mathrm{HA})$

In combination with carboxymethyl chitosan and ACP, form enamel-like apatite crystals and bind to demineralized enamel specifically

Nucleation of HA crystals and promotion of remineralization of initial carious lesions

Lv et al. (2015); Han et al. (2017); Kind et al. (2017); Mukherjee et al. (2019); Ding et al. (2020)

Chung and Huang (2013); Chung and Li (2013); Kind et al. (2017); Xiao et al. (2017); Ding et al. (2020)

Chung and Huang (2013); Chung and Li (2013); Kind et al. (2017); Xiao et al. (2017); Ding et al. (2020)
Promotes the uniform deposition of nanocrystalline calcium phosphate over demineralized enamel. Nucleates the formation of $\mathrm{HA}$ and inhibit demineralization
Hsu et al. (2011); Chung and Huang (2013); Chung and Li (2013); Yang et al. (2014); Yang et al. (2016); Alkilzy et al. (2018a); Ding et al. (2020)
Promotes HA crystals formation onto the enamel surface

Bind to $\mathrm{HA}$ and have a protective effect on $\mathrm{HA}$ against acid attack

Acts as a nucleation template
Chung and Huang (2013); Chung and Li (2013); Kind et al. (2017); Xiao et al. (2017); Ding et al. (2020)

Buzalaf et al. (2017); Valente et al. (2018); Arifa et al. (2019)

Yang et al. (2017)

(Continued on following page) 
TABLE 1 | (Continued) Synthetic peptides used for dental tissue regeneration.

\section{ENAMEL}

\begin{tabular}{ll}
\hline Peptide $\quad$ Methodology
\end{tabular}

Elastin-like polypeptide (E125) In vitro study in bovine enamel

Artificial lesions: $37 \%$ phosphoric acid for

$1 \mathrm{~min}$. Remineralization: Simulated oral fluid

(137.35 mM NaCl,4.17 mM NaHCO3,

$3.01 \mathrm{mM} \mathrm{KCl}, 7.17 \mathrm{mM} \mathrm{K} 2 \mathrm{HPO} 4 \bullet 3 \mathrm{H} 2 \mathrm{O}$,

$1.53 \mathrm{mM} \mathrm{MgCl} \bullet 6 \mathrm{H} 2 \mathrm{O}, 20 \mathrm{mM} \mathrm{HCl}$,

$0.90 \mathrm{mM} \mathrm{CaCl} 2,0.51 \mathrm{mM} \mathrm{Na} 2 \mathrm{SO} 4$ and tris)

at $37^{\circ} \mathrm{C}$ for $12 \mathrm{~h}, \mathrm{pH} 7.3$

P11-4 (N-terminally acetylated, Cpeptide)

The fourth-generation polyamidoamine dendrimer (PAMAM-Po3H2)

In vitro study in human third molars. Artificial lesions: $2.2 \mathrm{mM} \mathrm{CaCl}_{2}, 2.2 \mathrm{mM} \mathrm{NaH}_{2} \mathrm{PO}_{4}$, $50 \mathrm{mM}$ acetic acid; $\mathrm{pH} 4.4$ for 3 days at $37^{\circ} \mathrm{C}$. Remineralization: Buffer $2 \mathrm{mM}$ $\mathrm{Ca}\left(\mathrm{NO}_{3}\right)_{2}, 1.2 \mathrm{mM} \mathrm{KHPO}_{4}$, and $60 \mathrm{mM}$ Tris/ $\mathrm{HCl}(\mathrm{pH} 7.4)$ for 14 days

In vivo study, clinical application first an uncontrolled safety trial. Then randomized controlled trial (RCT) single-blinded study. $35 \%$ phosphoric acid and application of the peptide P11-4 and waiting for 3-5 min In vitro study in human third molars Artificial lesions: 37\% phosphoric acid. Remineralization: Artificial saliva $(1.5 \mathrm{mmol}$ $\mathrm{CaCl}_{2}, 0.9 \mathrm{mmol} \mathrm{K} \mathrm{HPO}_{4}, 130 \mathrm{mmol} \mathrm{KCl}$, $1 \mathrm{mmol} \mathrm{NaN}_{3}$ and $20 \mathrm{mmol}$ HEPES) $\mathrm{pH} 7$

ID4 and ID8 peptides self-assembly

In vitro study in bovine permanent incisors Artificial lesions: $50 \mathrm{mM}$ acetic acid $(\mathrm{pH} 4.5)$, $2.2 \mathrm{mM} \mathrm{Ca}\left(\mathrm{NO}_{3}\right)_{2}, 2.2 \mathrm{mM} \mathrm{KH}_{2} \mathrm{PO}_{4}, 5.0 \mathrm{mM}$ $\mathrm{NaN}_{3}$ and $0.5 \mathrm{ppm} \mathrm{NaF}$ at $37^{\circ} \mathrm{C}$ for 3 days and low-speed magnetic stirring (100 rpm). Remineralization: Artificial saliva $(1.5 \mathrm{mmol}$ $\mathrm{CaCl}_{2}, 0.9 \mathrm{mmol} \mathrm{K}_{2} \mathrm{HPO}_{4}, 130 \mathrm{mmol} \mathrm{KCl}$ $1 \mathrm{mmol} \mathrm{NaN}_{3}$ and $20 \mathrm{mmol}$ HEPES) $\mathrm{pH} 7$

\section{Effect}

\section{References}

Stabilizes ACP and induces the oriented crystal growth along the original enamel apatite nanocrystals, inducing the regeneration of enamel apatite crystal

structure

Induces the precipitation of HA to attract $\mathrm{Ca} 2+$ ions, regenerate early carious lesions (white spot lesions)

Lv et al. (2015); Han et al. (2017); Zhou et al. (2018)

Induces crystal remineralization with the same structure, orientation, and mineral phase of the intact enamel in a relatively short time

In combination with hydrogels could serve as the template to induce $\mathrm{HA}$ nucleation and promote biomimetic remineralization
Alkilzy et al. (2018a); GonzálezCabezas and Fernández (2018); Arifa et al. (2019); Jablonski-Momeni et al. (2019); Üstün and Aktören (2019); Kamal et al. (2020); Li et al. (2020)

\section{DENTIN}

\begin{tabular}{|c|c|}
\hline Peptide & Methodology \\
\hline $\begin{array}{l}\text { CPP-ACP Random from casein } \\
\text { digestion }\end{array}$ & $\begin{array}{l}\text { In vivo/In vitro studies in extracted intact human } \\
\text { third molar teeth. After demineralization, the } \\
\text { samples were cover with CPP-ACP and } \\
\text { incubated in artificial saliva }\end{array}$ \\
\hline P11-4 & In vitro study, extracted non-carious human third \\
\hline $\mathrm{CH}_{3} \mathrm{COQQRFEWEFEQQNH} \mathrm{H}_{2}$ & $\begin{array}{l}\text { molars were used to create an artificial carious } \\
\text { lesion and treated with the } \mathrm{P} 11-4 \text { peptide }\end{array}$ \\
\hline RAD/KLT peptide & In vitro studies to evaluate cell adhesion, viability, \\
\hline KLTWQELYQLKYKGI & $\begin{array}{l}\text { proliferation, morphology on hydrogel scaffolds, } \\
\text { and odontogenic differentiation of hDPSCs. Also } \\
\text { the proliferation, migration, and tube formation of } \\
\text { human umbilical vein endothelial cells (HUVECs) } \\
\text { cultured with hDPSCs/SAP-conditioned medium } \\
\text { In vivo study in a rat partially pulpotomized molar } \\
\text { model to evaluate the inductive role of the RAD/ } \\
\text { KLT peptides over rDPSC to induce tissue } \\
\text { regeneration after } 28 \text { days }\end{array}$ \\
\hline
\end{tabular}

\section{Effect}

Prevention of demineralization and enhancement of remineralization of enamel and dentin lesions. The enhancement of the bond strength at the resin/dentin interface during the restorative intervention To form hydroxyapatite crystals from supersaturated solutions/remineralization of caries lesions

Induce odontoblastic differentiation from dental pulp stem cells, and achieve dentin regeneration in vivo
Brunton et al. (2013); Kind et al. (2017); Alkilzy et al. (2018b); Arifa et al. (2019); Pandya and Diekwisch (2019); Üstün and Aktören (2019); Bröseler et al. (2020); Dissanayake et al. (2020); Farooq and Bugshan (2020); Wang et al. (2020)

Brunton et al. (2013); Kind et al. (2017); Alkilzy et al. (2018b); Arifa et al. (2019); Pandya and Diekwisch (2019); Üstün and Aktören (2019); Bröseler et al. (2020); Dissanayake et al. (2020); Faroog and Bugshan (2020); Wang et al. (2020) after 28 days 
TABLE 1 | (Continued) Synthetic peptides used for dental tissue regeneration.

\begin{tabular}{|c|c|c|c|}
\hline \multicolumn{4}{|c|}{ DENTIN } \\
\hline Peptide & Methodology & Effect & References \\
\hline CPD4 VNPKYKQKRR & $\begin{array}{l}\text { In vitro studies with dental pulp stem cells } \\
\text { (DPSCs) from human deciduous teeth. After } \\
\text { osteogenic differentiation under peptides and } \\
\text { proteins treatment, a Western blot (RUNX2, } \\
\text { Smad1/5/8, and pSmad1/5/8, Col1, OCN, OPN, } \\
\text { ALP, TAZ, and GAPDH) immunofluorescence } \\
\text { (OCN, DAPI) and histological staining (ALP) were } \\
\text { performed } \\
\text { In vivo, mouse calvarial defect model with defect } \\
\text { size of } 5 \text { mm, they used } 25 \text { animals in five groups } \\
\text { as follows: 1) defect, 2) non-treated (NT)/collagen, } \\
\text { 3) CDP4/collagen, 4) CPNE7/collagen, and 5) } \\
\text { BMP-2/collagen }\end{array}$ & $\begin{array}{l}\text { Cell penetration activity and regenerate } \\
\text { mineralized tissues like bone and dentin }\end{array}$ & $\begin{array}{l}\text { Creutz et al. (1998); Choung et al. } \\
\text { (2016); Seo et al. (2017); Lee et } \\
\text { al. (2019) }\end{array}$ \\
\hline $\begin{array}{l}\text { Dentonin } \\
\text { TDLQERGDNDISPFSGDGQPFKD }\end{array}$ & $\begin{array}{l}\text { In vivo study where agarose beads, either soaked } \\
\text { with dentonin or unloaded, were implanted into } \\
\text { the pulps of half-moon-shaped class } V \text { cavities on } \\
\text { the mesial aspect of the first maxillary rat molars } \\
\text { and examined } 8,15 \text {, and } 30 \text { days after treatment }\end{array}$ & $\begin{array}{l}\text { Enhances dental pulp stem cell proliferation } \\
\text { and promotes the regeneration of damaged } \\
\text { dentin }\end{array}$ & $\begin{array}{l}\text { Liu et al. (2004); Nagel et al. } \\
\text { (2004); Six et al. (2007) }\end{array}$ \\
\hline
\end{tabular}

PULP

\begin{tabular}{|c|c|c|c|}
\hline Peptide & Methodology & Effect & References \\
\hline
\end{tabular}

SLd

(TDLQERGDNDISPFSGDGQPFKD)

Leucine-Rich Amelogenin Peptide (LRAP)

Copine 7 derived peptide (Cpne7-DP) (KYKQKRRSYK)

PuraMatrix ${ }^{\mathrm{TM}}$

(RAD Ac-(RADA)4-NH2)
In vitro cytocompatibility and proliferation assays

with mouse 3 ТЗ fibroblasts, and a test for proliferation and efficacy with DSPCs and alizarin red staining were performed

In vivo test for biodegradation: Subcutaneous dorsal implantation in female wistar rats and histological staining

In vitro analyses included the effects of the addition of the recombinant proteins or peptides on cell proliferation, differentiation, and adhesion of postnatal human dental pulp cells (DPCs)

In vivo analyses were completed following the insertion of agarose beads containing LRAP or LRAP 8, 9 into exposed cavity preparations of rat molars. After 8,15 , or 30 days' exposure, the pulp tissues were analyzed for changes in histomorphometry and cell proliferation by PCNA staining

Human dental pulp cells (HDPCs) and a mouse pre-odontoblast cell line, MDPC-23, were chosen for in vitro studies to characterize lineage-specific cell responses after Cpne7-DP treatment In vivo Cpne7-DP was tested using a beagle dog model by generating dentinal defects of various degrees. Overall mineralization capacity of Cpne7DP was tested ex vivo

The peptide hydrogel PuraMatrix ${ }^{\mathrm{TM}}$ was used as a scaffold system to investigate the role of dental pulp stem cells (DPSCs) in triggering angiogenesis and the potential for regenerating vascularized pulp in vivo. Human umbilical vein endothelial cells (HUVECS), DPSCs, or co-cultures of both cell types were encapsulated in three-dimensional PuraMatrix ${ }^{\mathrm{TM}}$ in a SCID mouse model for subcutaneous transplantation of human tooth root fragments loaded with cell/PuraMatrix ${ }^{\mathrm{TM}}$ constructs
Enhances dental pulp stem cell proliferation

Nguyen et al. (2018)

Proliferation and differentiation of dental pulp cells

Huang et al. (2012)

Promotes dentin regeneration, differentiation Lee et al. (2020) cellular

Enables cell survival, cell migration, and capillary network formation in the absence of exogenous growth factors. Besides, DPSCs increases early vascular network formation and increases VEGF expression
Dissanayaka et al. (2015)

(Continued on following page) 
TABLE 1 | (Continued) Synthetic peptides used for dental tissue regeneration.

\begin{tabular}{|c|c|c|c|}
\hline \multicolumn{4}{|c|}{ PULP } \\
\hline Peptide & Methodology & Effect & References \\
\hline $\begin{array}{l}\text { Peptide hydrogel RADA16-I } \\
\left(\mathrm{COCH}_{3}-\mathrm{RADARADARADARADA}-\right. \\
\left.\mathrm{CONH}_{2}\right)\end{array}$ & $\begin{array}{l}\text { The } \beta \text {-sheet and grid structure were observed by } \\
\text { circular dichroism, SEM, and AFM. } \\
\text { Living cell staining, proliferation, cytoskeleton in } \\
\text { DPSCs. Migration assay in DPSCs and HUEVECs. } \\
\text { Western blot }\end{array}$ & $\begin{array}{l}\text { Self-assembly, microenvironment-simulating } \\
\text { extracellular matrix, therapeutic delivery }\end{array}$ & $\begin{array}{l}\text { Fermini et al. (2018); Mu et } \\
\text { al. (2020) }\end{array}$ \\
\hline $\begin{array}{l}\text { RAD/PRG - RAD/KLT } \\
\text { (RAD Ac-(RADA)4-NH2) } \\
\text { (PRG Ac (RADA) } \\
\text { 4GPRGDSGYRGDS-NH2) } \\
\text { (KLT Ac-(RADA) } \\
\text { 4G4KLTWQELYQLKYKGI- NH2) }\end{array}$ & $\begin{array}{l}\text { In vitro studies; hDPSCs were isolated from } \\
\text { extracted premolars and third molars without } \\
\text { caries or periodontal diseases. Human umbilical } \\
\text { vein endothelial cells (HUVECs) were obtained from } \\
\text { the Chinese academy of sciences (category } \\
\text { number: EAhy926). Rat DPSCs (rDPSCs) were } \\
\text { isolated from the lower incisors of 3-weeks- old } \\
\text { male sprague-dawley rats. Cell adhesion, viability, } \\
\text { proliferation, morphology, and odontogenic } \\
\text { differentiation assay were performed. } \\
\text { Angiogenesis-inducing Activity of hDPSCs/SAP- } \\
\text { Conditioned Medium in Matrigel matrix. In vivo; } \\
\text { thirty-five } 8 \text {-week-old male sprague-dawley rats } \\
\text { divided into } 7 \text { groups ( } n=5 \text { animals per group). In } \\
\text { groups, } 1 \text { through } 6 \text {, the dental pulp under the } \\
\text { occlusal surface of the left upper first molar was } \\
\text { exposed and partially pulpotomized the residual } \\
\text { pulp was implanted with one or a mixed SP with } \\
\text { rDPSCs for } 28 \text { days }\end{array}$ & $\begin{array}{l}\text { Shows an enhanced regenerative and reparative } \\
\text { effect on a pulpotomized molar rat model, } \\
\text { achieving pulp recovery and dentin regeneration }\end{array}$ & Xia et al. (2020) \\
\hline Multidomain peptide (MDP) & $\begin{array}{l}\text { An ex vivo mandible organ culture model was used. } \\
\text { MDP hydrogel scaffolds were injected either at the } \\
\text { interface of the odontoblasts and the dentin or into } \\
\text { the pulp core of mandible slices and subsequently } \\
\text { cultured for up to } 10 \text { days. Histological (alizarin red } \\
\text { staining) and immunohistochemical analysis (dentin } \\
\text { sialophosphoprotein, (collagen III, MMP2) were } \\
\text { performed }\end{array}$ & $\begin{array}{l}\text { Scaffolds design and self-assembly, release/ } \\
\text { delivery, and bioactivity }\end{array}$ & $\begin{array}{l}\text { Moore et al. (2015); } \\
\text { Seyhan, 2019, (172) }\end{array}$ \\
\hline $\begin{array}{l}\text { Calcitonin gene-related peptide } \\
\text { (CGRP) }\end{array}$ & $\begin{array}{l}\text { Commercially available DPSCs were treated with } \\
\text { varying doses of CGRP, and metabolic activity, } \\
\text { viability, proliferation, and cell death were evaluated } \\
\text { using 3-(4,5-dimethylthiazol-2yL)-2,5-diphenyl } \\
\text { tetrazolium bromide assays, trypan blue staining, } \\
\text { 5-bromo2'-deoxyuridine cell proliferation assay, } \\
\text { and caspase-3 staining, respectively. DPSC } \\
\text { differentiation was assessed with alizarin red } \\
\text { staining and by quantifying messenger RNA } \\
\text { expression of odontoblast makers }\end{array}$ & $\begin{array}{l}\text { Mediating neurogenic inflammation, vascular } \\
\text { and innervation in the pulp, and healing of } \\
\text { periapical lesions is extensively }\end{array}$ & $\begin{array}{l}\text { Caviedesbucheli et al. } \\
\text { (2008); Michot et al. (2020) }\end{array}$ \\
\hline
\end{tabular}

grown enamel-like layer exhibits well-regulated crystal growth and improved composition, structure, and mechanical properties of artificial enamel (Yarbrough et al., 2010; Buzalaf et al., 2017; Prajapati et al., 2018; Bröseler et al., 2020; Farooq and Bugshan, 2020).

The tyrosine-rich peptides (TRAP) domain derived from amelogenin N-terminus has been associated with matrix selfassembly meanwhile, the amelogenin central polyproline repeat region could control crystal spacing, and the hydrophilic C-terminus facilitates amelogenin protein solubility and its adhesion to the crystal surface (Han et al., 2017; Dissanayake et al., 2020; Farooq and Bugshan, 2020; Wang et al., 2020). On the other hand, leucine-rich peptides (LRAP) can promote both, enamel crystal nucleation and growth in mouse models (Ding et al., 2020). LRAP improves the remineralization of enamel surface lesions on extracted teeth in vitro more effectively than full-length amelogenin (Han et al., 2017; Dissanayake et al., 2020; Farooq and Bugshan, 2020; Wang et al., 2020) and has been modified with phosphorylation using a calcium and phosphaterich solution forming spherical nanoparticles in a linear chainlike pattern. These self-assembled peptides formed spherical amorphous calcium phosphate (ACP) particles and triggered ACP to hydroxyapatite phase transformation (Ieong et al., 2011; Bagheri et al., 2015; González-Cabezas and Fernández, 2018; Arifa et al., 2019; Mukherjee et al., 2019; Pandya and Diekwisch, 2019; Dissanayake et al., 2020; Farooq and Bugshan, 2020).

There is also an amelogenin repeat-based peptide that consists of 22-residues in five tandem polyproline repeat (GLn-Pro-X) and a seven residues hydrophilic tail. This peptide has shown the ability to promote the remineralization of enamel caries in an in vitro $\mathrm{pH}$-cycling system. Besides, it could bind on the enamel 
surface, and can stabilize ACP, meanwhile is able to control the crystallization of $\mathrm{HA}$, and promotes the remineralization of caries lesion (Lv et al., 2015; Han et al., 2017; Kind et al., 2017; Mukherjee et al., 2019; Ding et al., 2020). Finally, the chimeric peptide Ame-CT16-HA6-1 is formed by 16 carboxyl-terminal residues of amelogenin attached to a sequence of SVSVGMKSPRR denominated HA6-1. This peptide in combination with carboxymethyl chitosan and ACP forms enamel-like apatite crystals and binds to demineralized enamel specifically to achieve rapid remineralization (Chung and Huang, 2013; Chung and Li, 2013; Kind et al., 2017; Xiao et al., 2017; Ding et al., 2020).

An important non-amelogenin protein synthesized by ameloblast is tufteline, which induces and regulates the initial mineralization of enamel owing to its acidic nature. Tufteline contains a self-assembly domain near the $\mathrm{C}$-terminus and an anionic domain near the $\mathrm{N}$-terminus that could be involved in the initial crystallization of enamel. The tufteline derived peptide (TDP) has a significant effect on the nucleation of $\mathrm{HA}$ and remineralization of initial carious lesions in vitro, suggesting that this peptide has the potential to regenerate the structure and mechanical properties of enamel (Chung and Huang, 2013; Chung and Li, 2013; Kind et al., 2017; Xiao et al., 2017; Ding et al., 2020).

On the other hand, a dentin phosphoprotein (DPP)-derived peptide constituted of octuplet repeats of aspartate-serine-serine (8DSS), has been applied to the enamel surface to prevent leaching of ions from the enamel surface and to promote the uniform deposition of nanocrystalline calcium phosphate over demineralized enamel surface given that this peptide possesses the ability to bind calcium and phosphate ions from the saliva (Yarbrough et al., 2010; Hsu et al., 2011; Buzalaf et al., 2017; Bröseler et al., 2020; Farooq and Bugshan, 2020). When 8DSS is combined with fluoride shows a more effective synergistic interaction to inhibit demineralization, reducing the concentration of fluoride used to prevent caries. (Hsu et al., 2011; Chung and Huang, 2013; Chung and Li, 2013; Yang et al., 2014; Yang et al., 2016; Alkilzy et al., 2018a; Ding et al., 2020). Finally, an NSS peptide is obtained when an aspartate is replaced for asparagine from the DSS sequence of DPP. NSS enhances the formation of HA crystals onto the enamel surface when compared whit non-peptide treatment (Chung and Huang, 2013; Chung and Li, 2013; Kind et al., 2017; Xiao et al., 2017; Ding et al., 2020).

\section{Peptides Non-Derived from the Amino Acid Sequence of Enamel and Dentin Proteins}

Several studies have shown that specific salivary proteins such as histatin, statherin, mucins, and cystatins play an important role to protect against dental caries (Buzalaf et al., 2017; Valente et al., 2018; Arifa et al., 2019; Wang et al., 2020). For instance, statherin derived peptides containing at least $15 \mathrm{~N}$-terminal residues (StN21 and StN15) bind to HA and enhance remineralization (Buzalaf et al., 2017; Valente et al., 2018; Arifa et al., 2019). Also, the statherin-derived peptide (DpSpSEEKC) can act as a nucleation template and can gather calcium ions to a high concentration given its secondary structure or its negatively charged groups when is incubated in artificial saliva (Yang et al., 2017).

Another studied peptide is the elastin-like polypeptide (E125) which is rich in acidic amino acids and can stabilize ACP, and induces the orientation of crystal growth along the original enamel apatite nano-crystals, resulting in regeneration of the enamel apatite crystal structure including both the prismatic and inter-prismatic structures in oral simulated environment ( $\mathrm{LV}$ et al., 2015; Han et al., 2017; Zhou et al., 2018).

\section{Self-Assembled Peptides}

Regarding self-assembled peptides, these can form a threedimensional scaffold and can promote early caries/white lesion remineralization (Pandya and Diekwisch, 2019; Bröseler et al., 2020; Dissanayake et al., 2020; Farooq and Bugshan, 2020; Li et al., 2020). For instance, P11-4 is an N-terminally acetylated, C-terminal amidated, 11 amino acid residue peptide. This $\beta$-sheet forming self-assembling peptide possesses anionic groups in the side chains that attract $\mathrm{Ca}^{2+}$ ions, diffuses well into the body of the caries lesions due to its low viscosity, and triggers self-assembly within the lesion inducing the precipitation of HA in situ. A single application of P11-4 improves the appearance of white spot lesions after 180 days in a small-scale clinical study (Alkilzy et al., 2018a; González-Cabezas and Fernández, 2018; Arifa et al., 2019; Jablonski-Momeni et al., 2019; Üstün and Aktören, 2019; Kamal et al., 2020; Li et al., 2020). However, more evidence is still needed before this peptide can be used in caries prevention and regular therapy (Alkilzy et al., 2018a; González-Cabezas and Fernández, 2018; Arifa et al., 2019; Jablonski-Momeni et al., 2019; Üstün and Aktören, 2019; Kamal et al., 2020; Li et al., 2020).

In the case of the fourth-generation polyamidoamine dendrimer (PAMAM-Po3H2) which mimic the self-assembly behavior of amelogenins, it is used as an organic template to induce crystal remineralization with the same structure, orientation, and mineral phase of the intact enamel in a relatively short time (Brunton et al., 2013; Kind et al., 2017; Alkilzy et al., 2018b; Arifa et al., 2019; Pandya and Diekwisch, 2019; Üstün and Aktören, 2019; Bröseler et al., 2020; Dissanayake et al., 2020; Farooq and Bugshan, 2020; Wang et al., 2020). Another strategy is to form films by amyloid-like lysozyme to obtain $\beta$-sheet stacked, which are combined with synthetic peptide based on the functional domains of C-terminal of amelogenin to promotes the oriented growth of HA crystals, which have a hardness and interfacial bonding stability higher than those of enamel repaired by fluoride. (Brunton et al., 2013; Kind et al., 2017; Alkilzy et al., 2018b; Arifa et al., 2019; Pandya and Diekwisch, 2019; Üstün and Aktören, 2019; Bröseler et al., 2020; Dissanayake et al., 2020; Farooq and Bugshan, 2020; Wang et al., 2020).

ID4 and ID8 are peptides with shorter and optimized sequence patterns that are programmed to self-assembly into predefined conformations and nanostructures and in combination with hydrogels could serve as the template to induce HA nucleation and promote biomimetic remineralization of initial caries lesions. (Brunton et al., 2013; Kind et al., 2017; Alkilzy et al., 2018b; Arifa et al., 
2019; Pandya and Diekwisch, 2019; Üstün and Aktören, 2019; Bröseler et al., 2020; Dissanayake et al., 2020; Farooq and Bugshan, 2020; Wang et al., 2020).

\section{Dentin}

Dentin comprises the major mineralized part of the tooth and it is cover and protected by enamel in the tooth crown and surrounded by cementum in the radicular portion. The responsible cells in the dentin formation are the odontoblast, these cells are long-living post-mitotic cells (comparable to cardiomyocytes and neurons in the fact that they are stable and are not replaced throughout the whole life of a tooth) (Sasaki and Garant, 1996; Goldberg et al., 2011; Kawashima and Okiji, 2016). Its inorganic matrix is composed of HA crystals while its organic matrix is mainly composed of a collagenous structural component, formed of collagen type I (about 90\%), collagen type III and V, and a small quantity of organic matrix molecules (proteoglycans of chondroitin sulfate (biglycan and decorin), heparan sulfate (perlecan and entactin), keratan and dermatan sulfate. It has also non-collagen proteins that participate in the mineralization process. These proteins are members of the SIBLING family (small integrin-binding ligand $\mathrm{N}$-linked glycoprotein) and include the sialophosphoprotein (DSPP), dentin matrix protein 1 (DMP-1), osteopontin (OPN), matrix extracellular phosphoglycoprotein (MEPE), and integrin-binding sialoprotein (IBSP) (Huang et al., 2008; Zhang et al., 2010) Due to odontoblast specifically expresses DSPP and DMP-1, these proteins are considered specific markers for these cells (Staines et al., 2012).

The dentin-pulp complex regeneration has two major limitations: 1) When the reactionary dentin has been formed, is permeable and fragmentable, resulting in microorganisms recontamination. This problem is caused by the poor attachment of the biomaterials to the dentin and lack of dental pulp stem cells (DPSCs) induction. 2) The second limitation is the pulp necrosis which avoids the blood supply to the exposed wall. The approach to overcome these problems is to create strategies to improve the adhesion of the biomaterials to dentin, promoting the HA nucleation, and the development of scaffolds with molecules that provide signals for dentinogenesis (Piva et al., 2014; Fawzy El-Sayed et al., 2019; Moussa and Aparicio, 2019). In this regard, the development of peptide therapies and biomaterials functionalized with peptides to promote dentinogenesis in the dentin-pulp complex are increasing and are presented below.

\section{Casein Phosphopeptide with Amorphous Calcium Phosphate (CPP-ACP)}

This agent is based on a nano-complex of the milk protein caseinphosphopeptide (CPP) combined with ACP and it has been used for the prevention of demineralization and enhancement of remineralization of enamel and dentin lesions (Rahiotis and Vougiouklakis, 2007). Its mechanism of action involves the fixing of calcium phosphate under neutral or alkaline $\mathrm{pH}$ solutions and promoting their assembling in HA on the dentin surface. Its biological mechanism allows the replacement of the minerals in the intra and interfibrillar collagen spaces after demineralization is covered with CPPACP and incubated with artificial saliva. The experimental result of this therapy over dentin samples of extracted intact human third molar is the enhancement of the bond strength at the resin/dentin interface during the restorative intervention (Cao et al., 2013; Sattabanasuk et al., 2014). Nevertheless, the results do not reflect what occurs at the bonding interface in a clinical situation since some conditions cannot be replicated in vitro such as the volume of cement or cement thickness, the surface area of adhesion, and the cavity configuration.

\section{Self-Assembling Peptide P11-4}

P11-4 is a rational designed biomimetic peptide that has selfassembling behavior into beta-sheet fibrillar hydrogel at $\mathrm{pH}<7$ (Koch et al., 2018). This peptide attracts calcium ions and form HA crystals from supersaturated solutions such as saliva and binds to collagen I in dentin tissue acting as a protector against proteolytic activity of collagenases in artificial dentin caries. These characteristics show that this peptide could be as a pretreatment of caries-affected dentin enhancing significantly the performance of the bond interface over time (de Sousa et al., 2019).

\section{RAD/KLT Peptide}

KLT peptide is formed by the amino acids $17-25$ of the vascular endothelial growth factor (VEGF) and activates VEGF receptors inducing angiogenesis (D'Andrea et al., 2005). When this peptide is coupled to the beta-sheet self-assembling peptide RAD (AcRADARADARADA) to create the RAD/KLT peptide (Ac(RADA) ${ }_{4} \mathrm{G}_{4}$ KLTWQELYQLKYKGI- $\mathrm{NH}_{2}$ ) forms, a gel of nanofibers of $16 \mathrm{~nm}$ that induces the odontoblastic differentiation from DPSCs. When this peptide is mixed with the self-assembling PRG peptide (Ac(RADA) ${ }_{4}$ GPRGDSGYRGDS- $\mathrm{NH}_{2}$ ), provides binding motifs for integrins by directly coupling a 2 -unit RGD binding sequence to RAD (Xia et al., 2020). DPSCs grown on RAD/PRG/KLT shows improved survival and can be differentiated to angiogenic and odontogenic phenotypes in vitro. Histological and functional evaluations of a partially pulpotomized rat model showed its capability to stimulate pulp and dentin regeneration in vivo over the course of 28 days (Xia et al., 2020).

\section{Derived Peptides from Calcium Phospholipid-Binding Protein, Copine 7 Protein (CPNE7)}

The CPNE7 is a member of the family CPNE proteins which are $\mathrm{Ca}^{2+}$ dependent and phospholipid-binding proteins (Creutz et al., 1998), it induces reparative dentin and odontoblast differentiation from mesenchymal stem cells (Choung et al., 2016; Seo et al., 2017). Given its short half-life, some bioactive peptides derived from the sequence 321-360 (STTFEEMQKA FEEGQAQWDC VNPKYKQKRR SYKNSGVVL) region of CPNE7 have been developed. CPD4: VNPKYKQKRR, have shown an enhanced cell-penetrating activity as well as osteogenic efficiency in DPSCs. It also induces the expression of biomineralization markers in vitro and when is mixed with collagen gel, forms mineralized tissue in the calvaria rat defects model. These results suggest that CPD4 peptide has the potential to be used as a biotechnological material to 
regenerate mineralized tissues like bone and dentin (Lee et al., 2019).

\section{Dentonin}

Dentonin or AC-100 is an SP derived from the central region of MEPE protein (residues 242-264: TDLQERGDNDISPFSGDGQPFKD). This peptide includes an integrin-binding sequence (RGD), a glycosaminoglycanattachment sequence (SGDG), and a calcium-binding motif (Six et al., 2007). Dentonin peptide stimulates human bone marrow stromal cell proliferation and differentiation into osteoblast precursors and enhances dental pulp stem cell proliferation in vitro (Liu et al., 2004; Nagel et al., 2004). Also, it has been shown that agarose beads soaked with a solution of $5 \mathrm{mg}$ dentonin $/ 0.5 \mathrm{ml}$ PBS and implanted into rat molars pulps promote pulp cell proliferation and reparative dentin formation at day 8 , suggesting that dentonin promotes the regeneration of damaged dentin (Six et al., 2007).

\section{Dental Pulp}

The dental pulp is a soft ecto-mesenchymal tissue surrounded by dentin and it is highly vascularized and highly innerved. It consists of $75 \%$ water and $25 \%$ organic material. It contains a heterogeneous population of cells such as fibroblastic cells, stem cells, capillary blood vessels, peripheral nerves, lymphatic elements, as well as cells from the immune system, extracellular matrix represented by fibers, and fundamental substance. Collagen fibers are concentrated to form supporting elements for blood vessels and nerve trunks that course from the root apex to the coronal pulp chamber (Garant, 2003; Yoshida et al., 2020).

The pulp tissue is unique given its volume and its confinement within the dentin. It has little blood supply, except in the apical foramen, and lacks collateral blood supply, hindering infection eradication by the immune system (Yoshida et al., 2020). Dental pulp is an important component of teeth and plays important roles in 1) forming the dentin: this is the essential function of the pulp and it is maintained as long as the pulp is vital. The cells in charge of producing it are the odontoblasts. Depending on the moment in which it is produced, different types arise: primary, secondary and tertiary, 2) nutrition: the pulp is responsible for nourishing the dentine through the odontoblastic extensions and metabolites coming from the pulp vascular system, 3) sensitive: in the face of stimuli, aggression or pain, the pulp is capable of responding; in the sensitivity of the pulp, no matter the nature of the stimulus, there will always be a painful response, and 4) defense/repairing: it includes the ability to form dentin in the face of aggression (Zero et al., 2011; Mu et al., 2020).

Dental pulp is considered one of the most difficult tissues to regenerate given the loss of fibrous connective tissue and its anatomical distribution. The process of pulp regeneration begins with the revascularization as it plays a fundamental role in the reparative processes of dentin tissues and the homeostasis of the dentin-pulp complex itself (Saghiri et al., 2015; Kim, 2017; Jung et al., 2019). In the field of regenerative endodontics, the most important point is to provide a favorable environment to achieve the regeneration of the lost tissues. Thus, crucial factors such as cells, scaffolds, and signaling molecules are required.

\section{Peptides for Dentin-Pulp Complex Regeneration}

SLd peptide is a minimally invasive injectable peptide scaffold that was developed from Dentonin sequence and demonstrated to be a self-assembled platform to support DPSCs and stromal cells in a biomimetic hydrogel environment. This peptide supports the proliferation of DPSCs and increases calcium phosphate deposition being cytocompatible to other critical stromal cells found in the dental pulp (Nguyen et al., 2018).

In the case of LRAP plus amelogenin exons 8 and 9 peptide (LRAP 8, 9), it was used to determine their effects on odontoblasts and dental pulp cells (DPCs). In vitro LRAP 8, 9 demonstrated to promote DPCs proliferation and differentiation to a greater extent than LRAP. These data suggest that amelogenin exons 8 and 9 may be useful in amelogenin-mediated pulp repair cell proliferation (Huang et al., 2012).

Another peptide is Cpne7-DP, which can be placed on $0.5 \%$ fibrin gel and then transplanted subcutaneously into immunocompromised mice. Twelve weeks after the transplantation, the Cpne7-DP treatment group showed the formation of dentin-pulp-like tissue with cells inserting long cellular processes into the tubule-like structure formed within newly mineralized tissue (Lee et al., 2020).

\section{Peptide Scaffolds}

The self-assembling peptide hydrogel PuraMatrix ${ }^{\mathrm{TM}}$ is a repeating polymer of the amino acid sequence RADA and is formulated as an injectable scaffold that assembles into nanofibers when is exposed to physiologic concentrations of salts. The SP has been used to investigate the role of DPSCs in triggering angiogenesis and the potential to regenerate vascularized pulp in vivo. The nanofiber microenvironment provided by this SP enables cell survival, cell migration, and capillary network formation in the absence of exogenous growth factors. Besides, an in vivo study shows that DPSCs increases early vascular network formation and increases VEGF expression in a mice model (Dissanayaka et al., 2015).

The RADA16-I sequence is a self-assembled peptide hydrogel that has amino acids positively (arginine) and negatively (aspartic acid) charged, and hydrophobic residues (alanine). It promotes the formation of hydrophobic and hydrophilic faces for B-sheets; it also promotes the migration of cells like DPSCs and the angiogenesis of human umbilical vein endothelial cells $(\mathrm{Mu}$ et al., 2020). Another SP is the functionalized scaffold RAD/ PRG/KLT which shows an enhanced regenerative and reparative effect on a pulpotomized molar rat model, achieving pulp recovery and dentin regeneration in vivo (Xia et al., 2020).

The multidomain peptide (MDP) scaffolds can be used as injectables, bioactive, and biodegradable hydrogel scaffolds for tissue regeneration. It is a short sequence of amino acids that selfassemble to form fibers in an aqueous solution. The sequence $\mathrm{K}(\mathrm{SL})_{3} \mathrm{RG}(\mathrm{SL})_{3} \mathrm{KGRGDS}$ is compatible with the dental pulp and promotes differential responses depending on the cell type 
(Moore et al., 2015). It has been shown that subcutaneous transplantation of the hydrogel within dentin cylinders into immunocompromized mice led to the formation of a vascularized soft connective tissue similar to dental pulp, supporting the use of this biomaterial as a candidate for regenerative endodontics (Galler et al., 2012).

\section{Synthetic Neuropeptides}

Neuropeptides are defined as peptide neurotransmitters or neuromodulators. Multiple studies have demonstrated that trigeminal afferent neurons express Calcitonin gene-related peptide (CGRP), which innervates the dental pulp and also increases the expression of proteins associated with dentine formation in human pulp cells. CGRP and substance $\mathrm{P}$ mediate neurogenic inflammation and contribute to reparative dentin production and pulp tissue regeneration (Caviedesbucheli et al., 2008; Michot et al., 2020).

\section{PERIODONTAL REGENERATION}

The concept of periodontium includes a set of tissues that comprise the root cementum, alveolar bone, gingiva, and a functionally oriented PDL. Periodontal tissue damage affects dental organ support; hence, gingivitis and periodontitis are commonly caused by trauma or bacterial infection (Elango et al., 2020). These diseases attempt against periodontium homeostasis, causing tooth-loss (Polimeni et al., 2000).

As for every dental tissue replacement, it is necessary to mimic the physical and mechanical properties of naturally formed tissues (Yen and Yelick, 2011). Another challenge for restoring damaged periodontium is the fact that the inductive microenvironment given during the formation of periodontal tissues, is not the same after total development of the tooth (Liang et al., 2020). Although structure and function could be partially restored (Liang et al., 2020) through enamel matrix, grafting materials, guided tissue regeneration technique (GTRT), the use of growth factors, and stem cells, all of them present difficulties to be successful. Since natural microenvironmental characteristics are almost impossible to imitate, research focuses on biomimetic systems that combine natural or synthetic molecules like peptides (Table 2), amino acids and even cells with diverse biomaterials to build cell-3D scaffolds that enhance cell-material interactions (Elango et al., 2020). SP could be used as scaffolds or signals to achieve periodontal regeneration (Figure 2).

\section{Periodontal Ligament}

The PDL is a specialized connective tissue located around dental roots and serves as an anchor to the alveolar bone, controls tooth homeostasis, allowing its reparation and nutrition (Tomokiyo et al., 2019). The PDL consists of well-organized collagen fibers that anchor the root cement with alveolar bone, thus, is critical for periodontal regeneration (Liang et al., 2020). The extracellular matrix of these tissues is composed of members of the collagen family, proteoglycans, and a heterogeneous set of glycoproteins.
The PDL also acts as a sensory organ necessary for the proper positioning of the jaws during mastication with very high adaptability to rapid changes in applied forces and the capacity to maintain its width (McCulloch and Melcher, 1983). PDL fibroblasts are the dominant heterogeneous cell population in the PDL, being capable to differentiate into cementoblasts and osteoblasts (Roberts et al., 1982; McCulloch and Melcher, 1983). There is a low level of periodontal ligament stem cells (PDLSCs), which possess the capacity to differentiate into periodontal ligament fibroblasts, cementoblasts, and osteoblasts. In this regard, is important the distinction between PDLSCs and PDL fibroblast populations since PDLSCs are normally quiescent and can be only activated during tissue damage. Other cell types include the epithelial cell rests of Malassez, monocytes, macrophages, cementoblasts, osteoblasts, fibroblasts, myofibroblasts, nerve cells, epithelial cells, and endothelial cells (Barczyk et al., 2000; Bartold et al., 2000). Thus, PDL is a complex tissue and its regeneration is hampered since it is mandatory the control of infection and inflammation to then promote cell adhesion, proliferation, and differentiation for new tissue formation (Liang et al., 2020).

One of the first attempts for restoring PDL was the use of Enamel matrix derivative (EMD) obtained from animal tissue. Then, a synthetic oligopeptide derived from EMD was developed, showing enhancement of proliferation of PDLSCs (Kato et al., 2013). However, its functional mechanisms are still not entirely clear.

Another extensively studied peptide is the tri-amino acid sequence, arginine-glycine-aspartate (RGD) which has been demonstrated to improve the attachment of several cell types to different materials (Hautanen et al., 1989; Aota et al., 1994). Besides, RGD mixed with extracellular matrix (EMC) proteins, reduces the risk of immune reactivity or pathogen transfer (Bellis, 2011), and in vitro studies has shown that synthetic RDG conjugated with poly-L-lysine backbone and oligo-DL-alanine or with L-serine-oligo-DL-alanine increases cell adhesion and migration of PDL-derived cells, which is promising for periodontal regeneration (Khorolsuren et al., 2020). Also, the integrin-binding cyclic and linear synthetic RGD-EPRGDNYR has shown enhancement of attachment, cell proliferation, and spreading of PDLC, being the cyclic forms of EPRGDNYR-BSA the most effective (Grzesik et al., 1998). A fibronectin peptide containing their RGD and PHSRN sequences coupled with six glycines (G3PHSRNG6RGDG) is able to enhance attachment and spreading of human PDLC by increasing ERK1/2 activity. This SP could be used to improve the environment for PDLC and achieve periodontal regeneration (Kim et al., 2004).

The ameloblastin-derived peptide (VPAFPRQPGTPGVASL) was first related to an increase in cell attachment and proliferation of PDL cells (PDLC), acting as a growth factor during periodontal regeneration (Zeichner-David et al., 2006). Recent studies do not show effects over proliferation of PDLC, but a stimulating effect on the mineralization capacity of PDLC (Kitagawa et al., 2011).

A peptide matrix named dendritic lysine-appended polydiacetylene (Lys-PDA) has shown the promotion of cell 
TABLE 2 | Synthetic peptides used in periodontal tissues regeneration.

\section{PERIODONTAL LIGAMENT}

\begin{tabular}{ll}
\hline Peptide & \multicolumn{1}{c}{ Methodology } \\
\hline $\begin{array}{l}\text { Oligopeptide derived from EMD } \\
\text { (OP-EMD) (WYQNMIR) }\end{array}$ & $\begin{array}{l}\text { In vitro study with human mesenchymal stem cells. Solid-phase peptide } \\
\text { synthesis + "tea-bag" methodology, cell proliferation assay, alkaline } \\
\text { phosphatase activity, measurement of procollagen type 1 C-Peptide, } \\
\text { osteocalcin production, mineralization assay, extracellular signal-related } \\
\text { kinases (ERK) were performed }\end{array}$
\end{tabular}

Integrin-binding cyclic and linear synthetic RGD-EPRGDNYR. (EPRGDNYR) linear and cyclic
In vitro study with human PDLSCs. PDL cells adhesion, proliferation, and the novo protein synthesis in vitro
Fibronectin peptide containing their RGD and PHSRN sequences coupled with six glycines (FP-RGD-PHSRN) (G3PHSRNG6RGDG)

Ameloblastin peptide, based on the 16 amino acid sequence of the $\mathrm{N}$-terminal porcine ameloblastin. (AMB-DP) (VPAFPRQPGTPGVASL)

Dendritic lysine-appended polydiacetylene (Lys-PDA)

HydroMatrix (HydM)
In vitro study with human PDL cells. The cells were applied to peptidecoated wells at a density of $1 \times 10^{4} /$ well. After $1 \mathrm{~h}$ incubation at $37^{\circ} \mathrm{C}$, adhered cells were fixed, stained, and examined by phase contrasts microscopy for cell spreading assay. The attached PDL cells were solubilized with $2 \%$ sodium dodecyl sulfate (SDS) for the cell attachment assay by measuring absorbance at $595 \mathrm{~nm}$ in a microplate reader. Western blot analysis was performed to determine extracellular signalregulated kinase (ERK1/2) activity

In vitro study with PDLC. Ameloblastin peptide synthesized by a pink technology method, cell proliferation assay, and alkaline phosphatase activity, inhibition assay with anti-ameloblastin antibody, mineralization assay, and RT-PCR were performed

In vitro study with human PDLSCs. hPDL cell viability, adhesion, and spreading on Lys-PDA, FDA/PI live/dead assay, MTT assay, actin cytoskeleton staining, osteogenic differentiation, and alizarin red staining were performed

In vitro study with human PDLSCs. Measurement of adhesion and proliferation using real-time impedance analysis, cell viability assay, cell morphology studies, osteogenic differentiation, and real-time RT-PCR.
Effect

References

Enhanced proliferation of PDL cells, as well as ALP activity, expression of osteonectin, osteocalcin production, the formation of calcified nodules, and mineralization

For attachment, cell proliferation, and spreading, the cyclic forms of EPRGDNYR-BSA conjugate were most potent than linear conjugate. The effects of all collagen/conjugate mixtures were equivalent to that of type collagen

Enhances attachment and spreading of human PDLC by increasing ERK1/2 activity

Increase in cell attachment and proliferation of PDL cells.

Stimulates ALP activity in a dosedependent manner, promotes mineralized nodule formation by PDL cells, and upregulates ALP and bone sialoprotein (BSP)

Supports periodontal cell adhesion and differentiation. The functionalized electrospun PCL mat also promoted cell viability, adhesion, and spreading

PDL cells can adhere, migrate, Nagy et al. (2018) survive, proliferate, and differentiate into the osteogenic

direction on the HydM gel

Kato et al. (2013)

Grzesik et al. (1998)

Kim et al. (2004)

Zeichner-David et al. (2006); Kitagawa et al. (2011)

Das et al. (2019)

\section{ALVEOLAR BONE}

Peptide
Osteogenic growth peptide
(OGP 0)

(OGP 0)

BMP-2 peptide (BMP-2P) (KIPKASSVPTELSAISTLYLGGK)
In vitro studies include; cell isolation and primary osteogenic cell cultures, cell morphology, cell proliferation and viability, evaluation of total protein content, ALP activity, and mineralized matrix formation In vivo studies include a surgical protocol where 60 male adult rats divided into three experimental groups with five animals each: Group I (GI): BC and BC OGP (10-14), group II (GIl): BC-COL and BC-COL OGP (10-14) and group III (CG): Negative control group (no treatment) for periods at 1, 2, 4 and 16 weeks with a noncritical size bone defect $(2 \mathrm{~mm})$ in the femur. Histological, radiographic, and histomorphometric analyses were performed In vitro cytotoxicity assessment with the MTT assay using L929 mouse areolar fibroblasts

In vivo critical-sized alveolar defect model with sprague dawley rats. A standardized tooth extraction rodent model was used, and post extraction the defects were either filled with graft materials for the experimental groups or left unfilled for the control group. Radiographic and histopathological analyses were performed

\section{Effect}

Promotes proliferation, differentiation, and biomineralization of osteoblastic linage cells

Osteogenic differentiation and biomineralization
References

Saska et al. (2018)

(Continued on following page) 
TABLE 2 | (Continued) Synthetic peptides used in periodontal tissues regeneration.

\section{ALVEOLAR BONE}

\begin{tabular}{ll}
\hline Peptide $\quad$ Methodology &
\end{tabular}

Peptide derived from parathyroid In vitro, the expression of TNF- $\alpha, \mathrm{IL}-1 \beta$, and IL-6 was assessed by hormone residues $1-34$. (PTH1-34)

AMB/P-15

CGRP

RGD

HydroMatrix immunohistochemistry and western blot In vivo diabetic rats were treated subcutaneously with low-dose $(40 \mu \mathrm{g} / \mathrm{kg}$ once daily for 5 days per week), middle-dose $(80 \mu \mathrm{g} / \mathrm{kg})$ or high-dose $(160 \mu \mathrm{g} / \mathrm{kg})$ PTHrP1-34 peptide. Treatment continued for 12 weeks. Changes in periodontal tissues were confirmed by micro-computerized tomography assay and H\&E analysis

In vivo $7 \mathrm{~mm}$ diameter fenestrations were made with a trephine in the mid-root of both maxillary canines in each dog. Bone, periodontal ligament, and cementum were removed. Block sections were retrieved at 3 and 8 weeks for histologic processing

In vitro Quantitative real-time RT-PCR was performed for embryonic CGRP, VEGF-A, CD31, Col I, Col II, OPN, MMP-2, LYVE-1, and GAPDH. Also In situ hybridization of murine CGRP and VEGF-A

In vivo, they used mandible and tibia mouse at various times (E12.5, E14.5, E17.5, E18.5, P0, P1, and P5), then isolated total RNA and performed a RT-PCR

In vitro PDL cell cytotoxicity was tested with 3-[4, 5- dimethylthiazol-2yl]-2, 5diphenyl-2H-tetrazolium bromide assay. Cell migration toward the chitosanbased materials was analyzed with a trans-well migration assay In vivo Horizontal periodontal defect model was created in four maxillary and mandibular lateral incisors of Macaca nemestrina. Following periodontal therapy, the sites were transplanted with various regenerative materials: 1) chitosan, 2) RGD-modified chitosan, 3) PDL cell sheet with chitosan, 4) PDL cell sheet with RGD-modified chitosan. The periodontal tissue regeneration was evaluated clinically and radiographically. Gingival crevicular fluids were collected each week to evaluate cementum protein-1 (CEMP-1) expression with enzymelinked immunosorbent assay, while the biopsies were retrieved after 4 weeks for histological and microcomputed

In vitro study with human PDLSCs. Measurement of adhesion and proliferation using real-time impedance analysis, cell viability assay, cell morphology studies, osteogenic differentiation, and real-time RT-PCR.
Effect

Bone mineralization and an inhibitory effect on alveolar

bone resorption

Enhance fibroblast

attachment with greater regeneration of fenestration defects

Biomineralization and

vascularization

(2017)

Vastardis et al.

(2005)

Maeda et al.

Osteogenic differentiation of Nagy et al. (2018) PDLSCs

Higher alveolar bone density, Amir et al. (2020) as well as higher CEMP-1 protein expression. Adhesion and proliferation of osteoblasts

\section{RADICULAR CEMENTUM}

\section{Peptide}

CEMP-1-p1

Amelogenin-derived peptide 5 (ADP5)

\section{Methodology}

In vitro nucleation assay is a slow and controlled chemical reaction between the calcium and phosphate ions (without organic matrix) in a semisolid medium made of sodium metasilicate solution polymer at physiological $\mathrm{pH}$ and room temperature

In vitro studies where an alkaline phosphatase based mineralization model was used to investigate the mineralization behaviors of the peptides. Cell adhesion and proliferation experiments were accomplished using cultured human periodontal ligament (hPDL) fibroblasts

Ex vivo studies where the cementum-root stock blocks were prepared from single-rooted, extracted adult teeth. Cylindrical blocks of $4 \mathrm{~mm}$ diameter were cut from the acellular cementum, close to the cementoenamel junction the specimens were coated with the peptide and incubated. The mechanical properties of the cementomimetic layer were assessed by nanoindentation and qualitative mechanical abrasion tests

\section{Effect}

This peptide has been related to the formation of spherical mineral structures on a nanometric scale and with a well-defined growth center of octacalcium phosphate, a precursor of HA. Facilitate cell-free formation of a cementum-like hydroxyapatite mineral layer on demineralized human root dentin that supported attachment of periodontal ligament cells

\section{References}

Correa et al. (2019)

Gungormus et al (2012) 
TABLE 2 | (Continued) Synthetic peptides used in periodontal tissues regeneration.

\section{RADICULAR CEMENTUM}

\begin{tabular}{|c|c|c|c|}
\hline Peptide & Methodology & Effect & References \\
\hline BMP-6p & $\begin{array}{l}\text { In vivo studies in a rat model where surgery to create a bony window on the } \\
\text { buccal aspects of mandibular molar roots were performed. } 24 \text { male } \\
\text { sprague dawley rats were divided into four groups according to BMP } \\
\text { application }(0,1,3 \text {, and } 10 \text { microg, respectively). Animals were killed after } \\
28 \text { days and the mandible was taken for histological examination. } \\
\text { Histometric measurements were performed on sections selected from } \\
\text { three levels (coronal, middle, and apical levels; with } 240 \text { m apart from the } \\
\text { central) of the defect. New bone and cementum formation (including area } \\
\text { and thickness) were analyzed and compared }\end{array}$ & $\begin{array}{l}\text { Induces the formation of cellular } \\
\text { cementum-like tissue, with } \\
\text { Sharpey's fiber attachment after } \\
28 \text { days in a rat model }\end{array}$ & $\begin{array}{l}\text { Huang et al. } \\
\text { (2005) }\end{array}$ \\
\hline ABM/P-15 & $\begin{array}{l}\text { Case report a maxillary lateral incisor with advanced adult periodontitis that } \\
\text { was treatment planned for extraction was treated with sulcular incisions, } \\
\text { full-thickness flap reflection, debridement of granulomatous tissue from } \\
\text { the defect, placement of a notch in the root at the apical extent of calculus, } \\
\text { mechanical root planing, brief cleansing with citric acid, grafting with abm/ } \\
\text { p-15, wound closure with sutures, and placement of a periodontal } \\
\text { dressing. Biweekly to monthly recalls were made until removal of a small } \\
\text { block section biopsy at about } 6 \text { months }\end{array}$ & $\begin{array}{l}\text { In a human case shown favorable } \\
\text { histologic healing, including } \\
\text { cementum, } \\
\text { PDL, and alveolar bone on a } \\
\text { previously calculus and biofilm } \\
\text { contaminated zone }\end{array}$ & $\begin{array}{l}\text { Yukna et al. } \\
(2002)\end{array}$ \\
\hline Synthetic anabolic peptide (AP) & $\begin{array}{l}\text { In vivo study where periodontal defects were created bilaterally adjacent to } \\
\text { four mandibular teeth in five baboons. The plaque was allowed to } \\
\text { accumulate around wire ligatures placed into the defects. After } 2 \text { months, } \\
\text { the wire ligatures were removed, and a notch was placed at the base of the } \\
\text { defect. The four teeth were randomly treated with one of the following } \\
\text { treatments: 1) saline + ACS serving as the control, 2) AP + ACS, 3) saline + } \\
\text { beta-TCP serving as another control, or 4) AP + beta-TCP. The baboons } \\
\text { were sacrificed } 5 \text { months post-treatment, and histomorphometric } \\
\text { analyses were performed under masked conditions }\end{array}$ & $\begin{array}{l}\text { Induces new cementum } \\
\text { formation by the stimulation of } \\
\text { cell activity on the root surface }\end{array}$ & $\begin{array}{l}\text { Yamashita et al. } \\
\text { (2010) }\end{array}$ \\
\hline
\end{tabular}

\section{GINGIVA AND OTHER SOFT TISSUES}

\section{Peptide}

P2 (PLVPSQPLVPSQPLVP SQPQPP LPP)

KSL-W (KKWFWVKFK)

SV (SWYGLR)

\section{Methodology}

In vivo study has a split-mouth, randomized, placebo-controlled design. Test and control wounds were created on the palatal mucosa of 54 sprague-dawley rats. Wounds were histologically processed, and reepithelialization, leukocyte infiltration, and angiogenesis were assessed at days 1,3 , and 7 post-surgery

In vitro normal human gingival fibroblasts were cultured. t Of primary human gingival fibroblasts were incubated with different concentrations $(0,10,50$, or $100 \mu \mathrm{g} / \mathrm{ml}$ ) of peptide KSL-W and used to evaluate the effect of KSL-W on the attachment (phase-contrast microscopy, stained F-actin filaments) cell cycle analysis, a trypan blue exclusion assay to determine viable cell numbers was performed. MMP-1, MMP-2, TIMP-1, and TIMP-2 protein levels were analyzed by ELISA. Type I collagen assay system was used to evaluate the effect of peptide KSL-W on collagen gel contraction by gingival fibroblasts In vitro normal human-derived gingival fibroblasts (NHGF) and human oral mucosa keratinocytes (HOMK) were used for in vitro experiments. WST-1 assay. Either NHGF $(3.0 \times 104$ cells $)$ or HOMK $(4.0 \times 104$ cells $)$ were added into each well of 96 -well plates and cultured in a medium containing SV peptide $(20 \mathrm{ng} / \mathrm{ml})$, rSV peptide $(20 \mathrm{ng} / \mathrm{ml})$, or phosphate-buffered saline (PBS). Fibronectin (10 $\mu \mathrm{g} / \mathrm{ml})$-precoated 96 -well microplates were used for the adhesion assay. The boyden chamber principle was applied for the cell migration assay. A standard scratch wound healing assay was adopted to evaluate the motility of NHGF or HOMK.

In vivo study, a rat model was used. Male sprague-Dawley rats. An oral punch wound was prepared at the left buccal mucosa approximately 7-8 $\mathrm{mm}$ behind the angle of mouth. A 5-mm dermal biopsy punch was used for this purpose, and a full-thickness mucosal wound was created in each animal. After the preparation of the wound, SV peptide $(20 \mathrm{ng} / \mathrm{ml}, n=$ 5), rSV peptide (20 ng/ml, $n=5)$, or PBS ( $n=5$ ) was dividedly injected into four sites of wound periphery as a total amount of $1 \mathrm{ml}$ solution for each site. Immunohistochemical and photographic analyses were performed

\section{Effect}

References

Promotes epithelial migration, induces reduction of inflammation,

increased angiogenesis, and accelerated wound closure in the oral mucosa

Promotes gingival fibroblast

Park et al. (2017)

adhesion, cell growth and

enhances

the secretion of MMP1, MMP2,

and $\alpha$-smooth muscle actin

Is implicated in angiogenesis, and fibroblast differentiation into myofibroblasts in oral mucosa (2020)
Villa et al. (2015) regeneration 
adhesion and proliferation of isolated PDLC in vitro. However, by its structure, the main issue is to build a thick scaffold, and efforts are focused on finding a carrier material alternative to Lys-PDA (Das et al., 2019).

HydroMatrix (HydM; Sigma-Aldrich, St. Louis, MO, United States) is a nanofiber scaffold for tissue engineering which can self-assemble and shows ideal conditions for PDLSCs proliferation without morphological changes (Nagy et al., 2018).

\section{Alveolar Bone}

The alveolar bone is the portion of the maxilla and mandible that surrounds the teeth and represents the primary support structure for the teeth. Two of the main causes of alveolar bone loss are periodontitis and trauma (Fu and Yap, 2007). The procedures for the regeneration of the alveolar bone are mainly based on the use of natural or synthetic scaffolds and bioactive agents (Kao et al., 2015). However, there are some inherent limitations associated with biomaterials and traditional techniques (Soldatos et al., 2017). An interesting alternative is the design of biomaterials modified with bioactive peptides that can interact with the surrounding tissues through biomolecular recognition. As a treatment strategy, peptides offer many of the advantages of protein therapeutics while addressing some of their limitations (Jabbari, 2013).

\section{Osteogenic Growth Peptide}

Osteogenic growth peptide (OGP) is a naturally occurring molecule with a primary structure similar to the C-terminal end of histone $\mathrm{H} 4$, whose sequence contains a highly conserved 14 amino acid motif (Pigossi et al., 2016). Furthermore, OGP and OGP-(10-14) are potent regulators of marrow stromal cells, and as a soluble peptide, their main activity includes promoting proliferation, differentiation, alkaline phosphatase activity, and matrix mineralization of osteoblastic lineage cells (Chen et al., 2007; Fei et al., 2010; An et al., 2014). OGP has been incorporated into regenerative membranes used in the GTRT. For instance, it has been shown that membranes based on biopolymers combined with OGP-(10-14) stimulate the proliferation and activity of osteoblasts in vitro, as well as the repair of bone tissue in vivo (Saska et al., 2018). Both, in vitro and in vivo experiments showed that the material is beneficial for cell adhesion, has good biocompatibility, enhances the expressions of osteogenic-related genes, and accelerates bone regeneration. Moreover, a novel osteogenic polypeptide hydrogel-based in photo-cross-linked gelatin methacryloyl with photo-crosslinkable OGP has been proposed as a promising alternative for bone repair and regeneration (Qiao et al., 2020).

\section{Peptides Derived From Bone Morphogenic Proteins}

The bone morphogenetic proteins (BMPs) have great biomedical potential as osteogenic factors (McKay and Sandhu, 2002; Kelly et al., 2016). An attractive approach to reduce the BMPs side effects in bone regeneration such as bone overgrowth or immune response (Carragee et al., 2011), is to use peptides derived from the bioactive domains of rhBMP-2 or other osteoinductive proteins (Jabbari, 2013). Peptides derived mainly from BMP-2, BMP-7 and BMP-9 have been studied for their ability to promote osteogenic differentiation in vitro and bone formation in vivo (Wang et al., 2017). It has been shown that human mesenchymal stem cells cultured on functionalized nanopatterned substrates with immobilized BMP-2 peptide (KIPKASSVPTELSAISTLYLGGK) exhibited greater potential for osteogenic differentiation (Kim et al., 2013). A previous study revealed that the application of mineralized nanofiber segments loaded with the E7-conjugated BMP-2 peptide in rat maxillae defects enabled a sustained peptide release over 4 weeks. Also, the X-ray microtomography analysis of peptide-loaded nanofiber graft filled defects revealed approximately three times greater new bone volume and density in comparison to unfilled control defects (Boda et al., 2019).

\section{Parathyroid Hormone-Related Peptides}

Parathyroid hormone (PTH) is considered as one of the major systemic regulators of calcium metabolism and bone remodeling (Goltzman, 2018). The peptide derived from PTH residues 1-34 (PTH1-34) is one of the earliest artificially synthesized amino acid fragments that was approved for the prevention and treatment of osteoporosis (Tashjian and Gagel, 2006). In a previous placebo-controlled clinical trial, PTH1-34 was associated with improved clinical outcomes, greater resolution of alveolar bone defects, and accelerated osseous wound healing in the oral cavity (Bashutski et al., 2010). It has been revealed that an RGD modified polyethylene glycol hydrogel containing PTH1-34 exhibited a clear beneficial effect on bone regeneration in circumferential bone defects around dental implants in a dog model (Jung et al., 2007). Besides, a recent study, showed that adding PTH1-34 to a xenograft increased the hardness of regenerated bone and accelerated bone mineralization in reconstructing mandible defects of pigs (Emam et al., 2020). Also, PTH1-34 may prevent alveolar bone resorption in type 1 diabetic rats, and that its intermittent administration could play an anabolic role in alveolar bone (Zhang et al., 2017).

\section{Other Peptides}

Peptide P-15 is a highly conserved peptide analog of the cellular binding domain of type I collagen (Bhatnagar et al., 1999). A previous research reported that the application of an organic bone mineral graft coated with a biomimetic collagen peptide (ABM/P15) resulted in greater regeneration of fenestration defects in dogs at 8 weeks compared to controls (Vastardis et al., 2005). Additionally, it has been shown that ABM/P-15 associated with acellular dermal matrix, efficiently promotes the maintenance of the buccal-palatal dimension after tooth extraction in humans (Fernandes et al., 2011).

Another peptide that can be synthesized is the calcitonin generelated peptide (CGRP) which is widely distributed in bone tissue and is known to be closely associated with osteogenesis (Maeda et al., 2017). Also, the RGD SP constitutes a system of cell surface signaling that enhances cell attachment and spreading of osteoblasts onto scaffolds and graft material (Durrieu et al., 2004). A recent study revealed enhanced regeneration of the horizontal periodontal defect in RGD-modified chitosan 
macaque model, showing higher alveolar bone density than controls (Amir et al., 2020). Finally, HydM has even shown osteogenic differentiation on PDLSCs in vitro. Even though the study has shown the potential of the HydM scaffold, more studies in vitro and in vivo are needed (Nagy et al., 2018).

\section{Dental Cementum}

Dental cementum is a hard and avascular connective tissue located on the dental root, whose main function is to connect the fibers of the PDL that emerge from the alveolar bone to the dental organ. Two types of cementum can be distinguished according to the presence (cellular cementum) or absence of internal cells (acellular cementum). Their composition is distributed by approximately $50 \%$ of mineral matter, mainly $\mathrm{HA} \quad\left(\mathrm{Ca}_{10} \quad\left(\mathrm{PO}_{4}\right)_{6} \quad(\mathrm{HO})_{2}\right)$ and $50 \%$ of organic matrix, being type I collagen $90 \%$ of the organic composition. Another cement-related collagen protein includes type III collagen, involved in the development, repair, and regeneration of periodontal support structures (Nanci and Bosshardt, 2000).

The participation of dental cementum in processes such as maintaining stability and chewing charge distribution is crucial. Thus, when cementum is affected by periodontal disease or trauma, periodontal therapy must provide a root surface free of etiological factors to promote the reinsertion of collagen fibers and avoid the formation of pathological spaces that promote bacterial proliferation. Therefore, the success of periodontal regenerative therapy relies on the dental cementum, its health, and its well-regenerative capacities (Grzesik and Narayanan, 2002).

There are two typical cementum-specific proteins. The 3Hydroxyacyl coenzyme A dehydratase 1/Cementum Attachment Protein (HACD1/CAP), induces the nucleation, regulation, and direction of hydroxyapatite crystal growth and enhances regeneration of critical bone defects in rat calvaria. Cementum protein 1 (CEMP-1) (Arzate et al., 1992; Bermúdez et al., 2015; Villegas-Mercado et al., 2018) regulates the activity of cementoblasts by inducing differentiation and intervenes in the process of mineralization, migration, and proliferation of gingival fibroblasts. CEMP1 also promotes the nucleation of OCP crystals (Alvarez-Perez et al., 2006).

\section{Peptides Derived from the Amino Acid Sequence of Cementum Proteins}

Some SP derived from dental cementum proteins such as CEMP1 (CEMP-1-p1) and HACD1/CAP (CAP-pi) have biological activity associated with the in vitro biomineralization (Correa et al., 2019; Montoya et al., 2019; Montoya et al., 2020). CEMP-1p1 induces the formation of spherical mineral structures on a nanometric scale and with a well-defined growth center of OCP (Correa et al., 2019). CAP-pi shows inhibitory activity of mineral crystal nucleation and growth (Montoya et al., 2020). The behavior of CEMP1- derived peptides is related to their capacity to activate $\mathrm{Wnt} / \beta$-catenin signaling pathways, which is associated with the enhancement of the biomineralization process (Arroyo et al., 2020).

\section{Peptides Non-Derived from the Amino Acid Sequence of Cementum Proteins}

The amelogenin-derived peptide 5 (ADP5) enhances cell-free formation of a cementum-like HA mineral layer on demineralized human root dentin that supports attachment of periodontal ligament cells in vitro. Additionally, ADP5 has shown a kinetic control over calcium phosphate nucleation governed by interactions with precursor ions attracting $\mathrm{Ca}^{2+}$ and $\mathrm{PO}_{4}{ }^{3-}$ and creating an increased local supersaturation of those ions. Cell adhesion and cell proliferation assays on the surface of ADP5mediated cementum-like tooth material showed that the mineral layer favors adhesion and proliferation of periodontal cells. Thus, the cementomimetic layer formed by ADP5 could have the potential clinical application to repair diseased root surfaces and promote the regeneration of periodontal tissues (Gungormus et al., 2012).

The synthetic BMP- 6 polypeptide, induces a thicker formation of cellular cementum-like tissue, with the incorporation of Sharpey's fiber attachment when is applied to periodontal fenestration defect in rats, after 28 days of healing (Huang et al., 2005).

The ABM/P-15 SP has been used in a human histologic case demonstrating favorable histologic healing of cementum, PDL, and alveolar bone on a previously calculus- and biofilmcontaminated zone, demonstrating its regenerative potential (Yukna et al., 2002).

A 23-amino acid peptide that corresponds to the central region (242 through 264) of human MEPE, the synthetic anabolic peptide (AP) (Nagel et al., 2004) has effects on normal osteoblast precursor cells. When is combined with a-tricalcium phosphate and an absorbable collagen sponge as the carrier induces the formation of new periodontal tissue on the root surfaces, showing that the sites with AP have more cementum formation than control sites. These results suggest that AP may affect cementogenesis by stimulating cell activity on the root surface (Yamashita et al., 2010).

\section{Gingiva and Other Soft Tissues}

The gingiva is the oral mucosa that covers the alveolar bone and cervical part of the tooth. The gingiva is composed of a layer of epithelial tissue (divided into three functional compartments; gingival, sulcular, and junctional epithelium) and the connective tissue into superficial and deep compartments (Nanci and Bosshardt, 2000). The gingiva forms a physical barrier against oral bacterial and provides mechanical protection to the underlying tissues (Hassell, 2000). Given its protective nature, the gingiva is key for wound healing since is constantly exposed to trauma or bacterial products that lead to inflammatory and infectious events. (Häkkinen et al., 2000). Some authors claim that wound healing represents a conserved process while the cellular processes of oral soft tissue resemble the healing of skin wounds (Polimeni et al., 2000; Wikesjö and Selvig, 2000). Nevertheless, important differences occur since it is commonly stated that oral wounds heal better and with less scar formation than dermal wounds (Häkkinen et al., 2000; Sculean et al., 2014).

The normal response to injury involves three overlapping stages: 1) inflammation, 2) new tissue formation, and 3) 


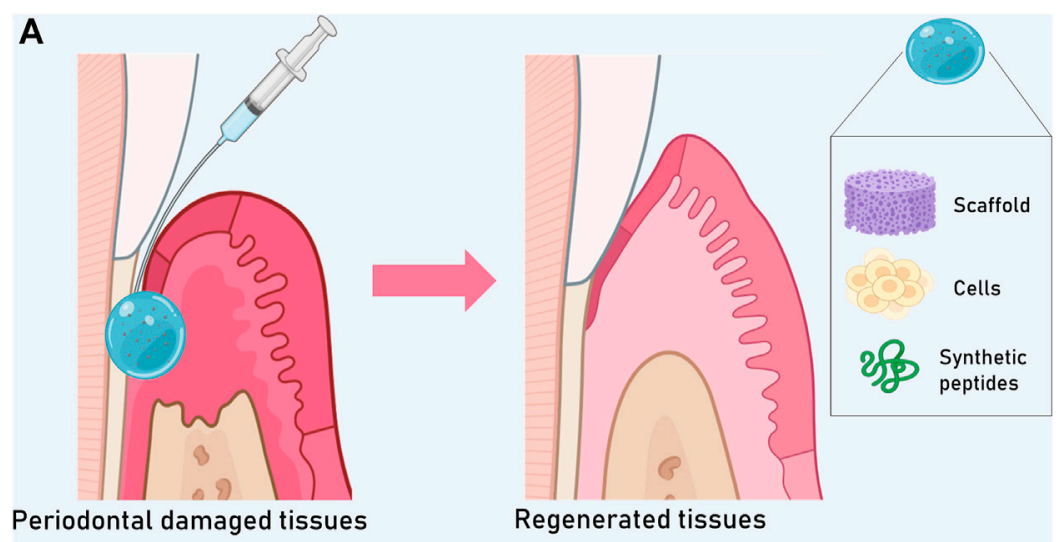

B

Synthetic peptides effects

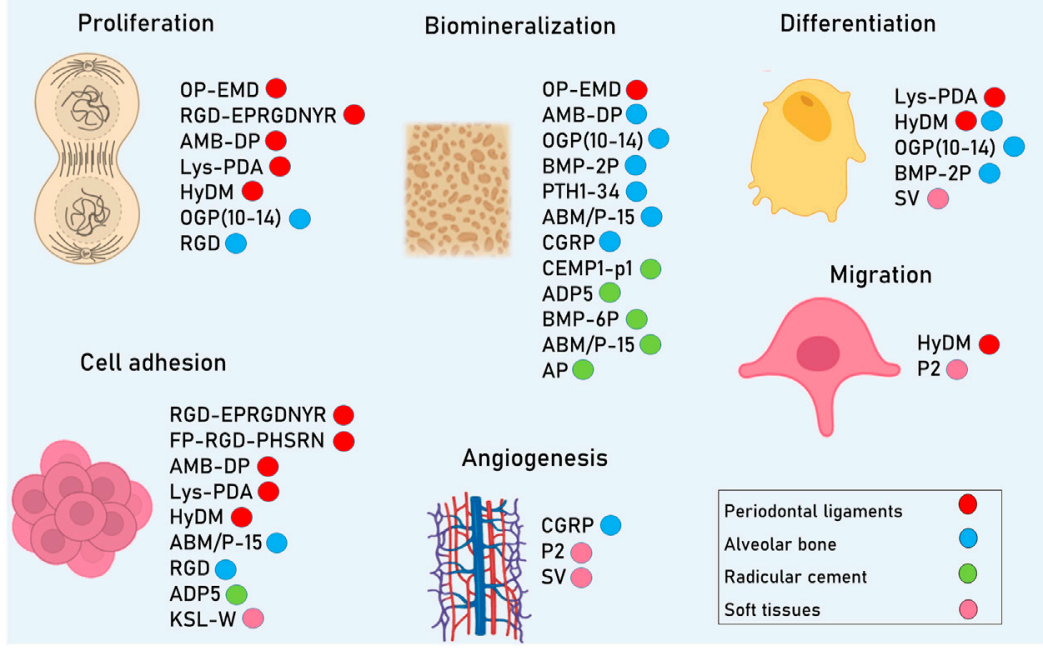

FIGURE 2 | Although the periodontium could be partially restored through tissue regeneration techniques, its complete regeneration is not possible yet since natural microenvironmental characteristics are almost impossible to imitate. (A) Research focuses on biomimetic systems that combine natural or synthetic molecules like peptides with scaffolds and cells to restore structure and function of the periodontal complex. (B) SP in periodontal cells are able to induce proliferation, migration, adhesion, angiogenesis, differentiation and biomineralization, enabling the formation of new tissue.

remodeling (Smith et al., 2015). After tissue injury, distinct biological pathways immediately become activated and are synchronized to prevent infection and restore the damaged tissues (Smith et al., 2015). The cells recruited during wound healing include components of the immune system, endothelial cells, keratinocytes, and fibroblast (Gurtner et al., 2008). In the last years, SP have arisen like a novel approach to enhance this process.

\section{Synthetic Proline-Rich Peptide (P2)}

The peptide P2 (PLVPSQPLVPSQPLVPSQPQPP LPP) was evaluated in a rat oral mucosal incisional wound healing model (Villa et al., 2015). P2 SP was previously shown to promote mesenchymal stem cell differentiation, induces bone formation, and mineralization in vitro (Ramis et al., 2012; Petzold et al., 2013). P2 enhances epithelial migration over the wound, reduces inflammation, increases angiogenesis, and accelerates the wound closure. P2 peptide contains proline-rich sequences, which are related to the immune response, wound repair (Zanetti, 2004), and angiogenesis (Li et al., 2000).

\section{Antimicrobial Peptide KSL-W}

The synthetic decapeptide KSL-W (KKVVFWVKFK) has an antimicrobial effect, promotes gingival fibroblast adhesion by increasing F-actin production, enhances cell growth by increasing the $S$, and induces $G 2 / M$ cell cycle phases. Besides, increases the secretion of MMP-1, MMP-2, and the expression of $\alpha$-smooth muscle actin, inducing wound healing (in the wound scratch assay) at 50 and $100 \mu \mathrm{g} / \mathrm{ml}$. Also, KSL-W induces activation/differentiation of gingival fibroblast to myofibroblasts at the wound site contributing to tissue repair (Park et al., 2017). 


\section{Synthetic Peptide SV}

An osteopontin-derived 7-amino-acid (SVVYGLR) SV is implicated in angiogenesis and fibroblasts differentiation to myofibroblasts. SV peptide induces cell migration of oral fibroblast and keratinocytes by activation of TGF- $\beta /$ Smad signaling pathway in vitro. In vivo, the SV peptide accelerates the healing process of oral mucosal wounds by facilitating angiogenesis and increasing the production of fibroblasts and myofibroblasts in a rat-oral wound model (Tanaka et al., 2020).

\section{CLINICAL IMPLICATIONS AND SIDE EFFECTS}

Until now, it is well-known that human dental tissues once formed cannot be biologically repaired or replaced. And their complex configurations demand different strategies for regeneration. In this regard, enamel and dentin require the use of cells in 3-D scaffolds for their eventual mineralization meanwhile pulp tissue requires processes such as revascularization and innervation. Thus, regenerative approaches and their potential clinical implementation remain a challenging task to achieve.

From a clinical perspective, SP combined with conventional treatments or alone can enhance remineralization or increase thickness and mechanical properties of the regenerated enamel and dentin. Furthermore, short peptides are not targeted for hydrolytic enzymes in the oral cavity, and some of them have minimal or null toxicity since their sequences are derived from natural proteins. Nevertheless, most of them remain under experimental investigation on in vitro cell models and preclinical models and have to be validated to determine their effectiveness, and the dose to be used.

To bridge the gap between in vitro and in vivo, one approach is mathematical modeling which is used to support clinical predictions, providing richer data sets for model calibration, facilitating a model-based translation of in vitro cell assays to in vivo response (Lee et al., 2013; Checkley et al., 2015). Another strategy is the use of clinical trials in a dish (CTiD) which bridges preclinical testing and clinical trials allowing to test potential therapies for safety or efficacy on cells collected from a representative sample of human patients (Fermini et al., 2018; Seyhan, 2019).

Nowadays, for dental tissues, only P11-4 has been used in a clinical trial on children aged $>5$ years with visible active early caries on erupting permanent molars, showing enamel tissue regeneration and prevention of lesion progression (Alkilzy et al., 2018b). These results could change the clinical approach, avoiding additional loss of healthy tissue.

Regarding periodontal tissues, due to their complex composition, regenerative biomaterials should be capable to interact with hard and soft tissues at the same time (Elango et al., 2020). Many options have been studied in vitro with promising results that may lead to preclinical studies (Nagy et al., 2018). In this regard, it has to be considered that the success of the translation research from bench to bedside depends on the adoption of multidisciplinary strategies to overcome each of the many problems during the development process of SP therapy.

In normal conditions, PDL is under the influence of occlusal mechanical forces. However, these conditions cannot be completely achieved during in vitro or ex vivo tests. The in vivo model is the unique option that can imitate the occlusal state to support the functional regeneration design. Another challenge is the Sharpey's fiber regeneration and their insertion. The fibers absence nullify this important connection, defeating the tooth support and occlusal force (Liang et al., 2020).

Given this intricate relationship, few clinical studies using SP have shown regeneration. For instance, ABM/P-15, shows a favorable histologic healing, finding cementum, PDL, and alveolar bone on a previously calculus- and biofilmcontaminated zone, demonstrating its regenerative potential (Yukna et al., 2002).

In the case of SP used to promote bone healing and regeneration, most of them have only been evaluated in vitro or in preclinical animal studies. Among the SP reported for alveolar regeneration, $\mathrm{PTH} 1-34$ and $\mathrm{P}-15$ have more extensive clinical use and are commercially available. PTH1-34 has therapeutic potential for oral bone lesions in periodontitis (Magda, 2010) and PepGen P-15 has been tested in human periodontal bone defects with favorable results (Pountos et al., 2016).

Regarding soft tissue, its healing and stability are essential to obtain predictive results from other regenerative procedures. Wound healing can be promoted by the application of SP to induce an accelerated wound healing, which should also benefit the clinical outcome of oral surgical procedures by assuring that the wound is more rapidly sealed off from the contaminated oral environment. This will lead to a more rapid connective tissue reorganization and contribute to a faster gain in wound strength, reducing the potential for scarring and scar tissue contraction (Villa et al., 2015).

Oral tissues work as an integrated unit and during their development, some proteins can participate in more than one tissue. This fact has led researchers to test the function of some SP designed for one tissue in another closely related one. In this regard, some promising SP could induce biomineralization in enamel, dentin, cementum, and alveolar bone, and other SP could function for regeneration of dentin-pulp and periodontal tissue complexes.

\section{CONCLUDING REMARKS}

SP used for oral tissue regeneration offer several advantages including increased specificity, small size, excellent safety, less immunogenicity, great stability, low risk of systemic toxicity, and low cost. Additionally, SP can be combined with scaffolds and cells, to induce cellular processes such as adhesion, proliferation, migration, differentiation, angiogenesis, and biomineralization that are required given the complex nature of oral tissues.

Even though most of the SP are still under investigation, some of them have been studied in vitro and in vivo with promising results that may lead to preclinical studies. There are SP that have 
shown their efficacy in clinical trials such as P11-4 for enamel regeneration or caries prevention and $\mathrm{ABM} / \mathrm{P}-15$ for cementum, PDL, and alveolar bone on a previously calculus- and biofilmcontaminated zone. Also, some SP are commercially available such as PTH1-34 and PepGen P-15 which are used for bone defects treatment.

Finally, the use of SP could become a more accessible therapy for the treatment of damaged oral tissues, thus replacing the use of inert materials or therapies with recombinant proteins and growth factors that are currently highly used in practice dental. Nevertheless, well-designed clinical studies need to prove their value before they can be broadly used.

\section{REFERENCES}

Abou Neel, E. A., Chrzanowski, W., Salih, V. M., Kim, H. W., and Knowles, J. C. (2014). Tissue engineering in dentistry. J. Dent. 42 (8), 915-928. doi:10.1016/j. jdent.2014.05.008

Alkilzy, M., Santamaria, R. M., Schmoeckel, J., and Splieth, C. H. (2018a). Treatment of carious lesions using self-assembling peptides. Adv. Dent Res. 29 (1), 42-47. doi:10.1177/0022034517737025

Alkilzy, M., Tarabaih, A., Santamaria, R. M., and Splieth, C. H. (2018b). Selfassembling peptide P11-4 and fluoride for regenerating enamel. J. Dent Res. 97 (2), 148-154. doi:10.1177/0022034517730531

Alvarez-Perez, M. A., Narayanan, S., Zeichner-David, M., Rodriguez Carmona, B., and Arzate, H. (2006). Molecular cloning, expression and immunolocalization of a novel human cementum-derived protein (CP-23). Bone. 38 (3), 409-19. doi:10.1016/j.bone.2005.09.009

Amir, L. R., Soeroso, Y., Fatma, D., Sunarto, H., Sulijaya, B., Idrus, E., et al. (2020). Periodontal ligament cell sheets and RGD-modified chitosan improved regeneration in the horizontal periodontal defect model. Eur. J. Dent. 14 (2), 306-314. doi:10.1055/s-0040-1709955

An, G., Xue, Z., Zhang, B., Deng, Q. K., Wang, Y. S., and Lv, S. C. (2014). Expressing osteogenic growth peptide in the rabbit bone mesenchymal stem cells increased alkaline phosphatase activity and enhanced the collagen accumulation. Eur. Rev. Med. Pharmacol. Sci. 18 (11), 1618-1624.

Aota, S., Nomizu, M., and Yamada, K. M. (1994). The short amino acid sequence Pro-His-Ser-Arg-Asn in human fibronectin enhances cell-adhesive function. J. Biol. Chem. 269 (40), 24756-24761. doi:10.1016/s0021-9258(17)31456-4

Arifa, M. K., Ephraim, R., and Rajamani, T. (2019). Recent advances in dental hard tissue remineralization: a review of literature. Int. J. Clin. Pediatr. Dent 12 (2), 139-144. doi:10.5005/jp-journals-10005-1603

Arroyo, R., López, S., Romo, E., Montoya, G., Hoz, L., Pedraza, C., et al. (2020). Carboxy-terminal cementum protein 1-derived peptide 4 (cemp1-p4) promotes mineralization through wnt/ $\beta$-catenin signaling in human oral mucosa stem cells. Int. J. Mol. Sci. 21 (4), 1307. doi:10.3390/ijms21041307

Arzate, H., Olson, S. W., Page, R. C., Gown, A. M., and Narayanan, A. S. (1992). Production of a monoclonal antibody to an attachment protein derived from human cementum. Faseb j. 6 (11), 2990-2995. doi:10.1096/fasebj.6.11. 1644261

Bagheri, G. H., Sadr, A., Espigares, J., Hariri, I., Nakashima, S., Hamba, H., et al. (2015). Study on the influence of leucine-rich amelogenin peptide (LRAP) on the remineralization of enamel defects via micro-focus $\mathrm{x}$-ray computed tomography and nanoindentation. Biomed. Mater. 10 (3), 035007. doi:10. 1088/1748-6041/10/3/035007

Banting, F. G., Best, C. H., Collip, J. B., Campbell, W. R., and Fletcher, A. A. (1922). Pancreatic extracts in the treatment of diabetes mellitus. Can. Med. Assoc. J. 12 (3), 141-146.

Barczyk, M., Bolstad, A. I., and Gullberg, D. (2000). Role Integrins Periodontal Ligament: Organizers Facilitators. Periodontol 2000. 63 (1), 29-47. doi:10.1111/ prd. 12027

Bartold, P. M., Shi, S., and Gronthos, S. (2000). Stem cells and periodontal regeneration. Periodontol. 2000. 40 (40), 164-172. doi:10.1111/j.1600-0757. 2005.00139.x

\section{AUTHOR CONTRIBUTIONS}

$\mathrm{MB}, \mathrm{LH}, \mathrm{GM}, \mathrm{AP}-\mathrm{S}$, ER, US-B, and CV-M conceived and designed the content of this review; MB, LH, GM, MN, AP-S, ER, US-B, JG-P, MA-M, RR-P, and CV-M wrote de paper; all authors contributed to the final version of the paper and approved the submitted version.

\section{FUNDING}

Partially supported by UNAM PAPIIT IN206420 and IN204120.

Bashutski, J. D., Eber, R. M., Kinney, J. S., Benavides, E., Maitra, S., Braun, T. M., et al. (2010). Teriparatide and osseous regeneration in the oral cavity. N. Engl. J. Med. 363 (25), 2396-2405. doi:10.1056/NEJMoa1005361

Bellis, S. L. (2011). Advantages of RGD peptides for directing cell association with biomaterials. Biomaterials 32 (18), 4205-4210. doi:10.1016/j.biomaterials.2011. 02.029

Bermúdez, M., Imaz-Rosshandler, I., Rangel-Escareño, C., Zeichner-David, M., Arzate, H., and Mercado-Celis, G. E. (2015). CEMP1 induces transformation in human gingival fibroblasts. PLoS One. 10 (5), e0127286. doi:10.1371/journal. pone.0127286

Bhatnagar, R. S., Qian, J. J., Wedrychowska, A., Sadeghi, M., Wu, Y. M., and Smith, N. (1999). Design of biomimetic habitats for tissue engineering with P-15, a synthetic peptide analogue of collagen. Tissue Eng. 5 (1), 53-65. doi:10.1089/ ten.1999.5.53

Bleicher, F. (2014). Odontoblast physiology. Exp. Cel Res. 325 (2), 65-71. doi:10. 1016/j.yexcr.2013.12.012

Boda, S. K., Almoshari, Y., Wang, H., Wang, X., Reinhardt, R. A., Duan, B., et al. (2019). Mineralized nanofiber segments coupled with calcium-binding BMP-2 peptides for alveolar bone regeneration. Acta Biomater. 85, 282-293. doi:10. 1016/j.actbio.2018.12.051

Bröseler, F., Tietmann, C., Bommer, C., Drechsel, T., Heinzel-Gutenbrunner, M., and Jepsen, S. (2020). Randomised clinical trial investigating self-assembling peptide P11-4 in the treatment of early caries. Clin. Oral Investig. 24 (1), 123-132. doi:10.1007/s00784-019-02901-4

Brunton, P. A., Davies, R. P., Burke, J. L., Smith, A., Aggeli, A., Brookes, S. J., et al. (2013). Treatment of early caries lesions using biomimetic self-assembling peptides--a clinical safety trial. Br. Dent J. 215 (4), E6. doi:10.1038/sj.bdj.2013.741

Buzalaf, M. A. R., and Jp Pessan, I. (2017). New preventive approaches Part I: functional peptides and other therapies to prevent tooth demineralization. Monogr. Oral Sci. 26, 88-96. doi:10.1159/000479350

Cao, Y., Mei, M. L., Xu, J., Lo, E. C., Li, Q., and Chu, C. H. (2013). Biomimetic mineralisation of phosphorylated dentine by CPP-ACP. J. Dent. 41 (9), 818-825. doi:10.1016/j.jdent.2013.06.008

Carragee, E. J., Hurwitz, E. L., and Weiner, B. K. (2011). A critical review of recombinant human bone morphogenetic protein-2 trials in spinal surgery: emerging safety concerns and lessons learned. Spine J. 11 (6), 471-491. doi:10. 1016/j.spinee.2011.04.023

Caviedesbucheli, J., Munoz, H., Azueroholguin, M., and Ulate, E. (2008). Neuropeptides in dental pulp: the silent protagonists. J. Endodontics. 34 (7), 773-788. doi:10.1016/j.joen.2008.03.010

Checkley, S., MacCallum, L., Yates, J., Jasper, P., Luo, H., Tolsma, J., et al. (2015). Bridging the gap between in vitro and in vivo: dose and schedule predictions for the ATR inhibitor AZD6738. Sci. Rep. 5 (1), 13545. doi:10. 1038/srep 13545

Chen, Z. X., Chang, M., Peng, Y. L., Zhao, L., Zhan, Y. R., Wang, L. J., et al. (2007). Osteogenic growth peptide C-terminal pentapeptide [OGP(10-14)] acts on rat bone marrow mesenchymal stem cells to promote differentiation to osteoblasts and to inhibit differentiation to adipocytes. Regul. Pept. 142 (1-2), 16-23. doi:10. 1016/j.regpep.2007.01.003

Choung, H. W., Lee, D. S., Lee, J. H., Shon, W. J., Lee, J. H., Ku, Y., et al. (2016). Tertiary dentin formation after indirect pulp capping using protein CPNE7. J. Dent Res. 95 (8), 906-912. doi:10.1177/0022034516639919 
Chung, H. Y., and Huang, K. C. (2013). Effects of peptide concentration on remineralization of eroded enamel. J. Mech. Behav. Biomed. Mater. 28, 213-221. doi:10.1016/j.jmbbm.2013.08.004

Chung, H. Y., and Li, C. C. (2013). Microstructure and nanomechanical properties of enamel remineralized with asparagine-serine-serine peptide. Mater. Sci. Eng. C Mater. Biol. Appl. 33 (2), 969-973. doi:10.1016/j.msec.2012.11.031

Correa, R., Arenas, J., Montoya, G., Hoz, L., López, S., Salgado, F., et al. (2019). Synthetic cementum protein 1-derived peptide regulates mineralization in vitro and promotes bone regeneration in vivo. FASEB J. 33 (1), 1167-1178. doi:10. 1096/fj.201800434RR

Creutz, C. E., Tomsig, J. L., Snyder, S. L., Gautier, M. C., Skouri, F., Beisson, J., et al. (1998). The copines, a novel class of C2 domain-containing, calciumdependent, phospholipid-binding proteins conserved from Paramecium to humans. J. Biol. Chem. 273 (3), 1393-1402. doi:10.1074/jbc.273.3.1393

D’Andrea, L. D., Iaccarino, G., Fattorusso, R., Sorriento, D., Carannante, C., Capasso, D., et al. (2005). Targeting angiogenesis: structural characterization and biological properties of a de novo engineered VEGF mimicking peptide. Proc. Natl. Acad. Sci. USA. 102 (40), 14215-14220. doi:10.1073/pnas. 0505047102

Dang, T., and Süssmuth, R. D. (2017). Bioactive peptide natural products as lead structures for medicinal use. Acc. Chem. Res. 50 (7), 1566-1576. doi:10.1021/ acs.accounts.7b00159

Das, E. C., Dhawan, S., Babu, J., Anil Kumar, P. R., Kumary, T. V., Haridas, V., et al. (2019). Self-assembling polymeric dendritic peptide as functional osteogenic matrix for periodontal regeneration scaffolds-an in vitro study. J. Periodontal Res. 54 (5), 468-480. doi:10.1111/jre.12647

de Sousa, J. P., Carvalho, R. G., Barbosa-Martins, L. F., Torquato, R. J. S., Mugnol, K. C. U., Nascimento, F. D., et al. (2019). The self-assembling peptide P11-4 prevents collagen proteolysis in dentin. J. Dent Res. 98 (3), 347-354. doi:10. $1177 / 0022034518817351$

Ding, L., Han, S., Wang, K., Zheng, S., Zheng, W., Peng, X., et al. (2020). Remineralization of enamel caries by an amelogenin-derived peptide and fluoride in vitro. Regen. Biomater. 7 (3), 283-292. doi:10.1093/rb/rbaa003

Dissanayaka, W. L., Hargreaves Km Fau - jin, L., Jin L Fau - samaranayake, LP., Samaranayake Lp Fau - Zhang, C., and Zhang, C. (2015). The interplay of dental pulp stem cells and endothelial cells in an injectable peptide hydrogel on angiogenesis and pulp regeneration in vivo. Tissue Eng Part A. 21 (3-4), 550-63. doi:10.1089/ten.TEA.2014.0154

Dissanayake, S. S. M., Ekambaram, M., Li, K. C., Harris, P. W. R., and Brimble, M. A. (2020). Identification of key functional motifs of native amelogenin protein for dental enamel remineralisation. Molecules 25 (18), 4214. doi:10.3390/ molecules25184214

Durrieu, M. C., Pallu, S., Guillemot, F., Bareille, R., Amédée, J., Baquey, C. H., et al. (2004). Grafting RGD containing peptides onto hydroxyapatite to promote osteoblastic cells adhesion. J. Mater. Sci. Mater. Med. 15 (7), 779-786. doi:10. 1023/b:jmsm.0000032818.09569.d9

Elango, J., Selvaganapathy, P. R., Lazzari, G., Bao, B., and Wenhui, W. (2020). Biomimetic collagen-sodium alginate-titanium oxide (TiO2) 3D matrix supports differentiated periodontal ligament fibroblasts growth for periodontal tissue regeneration. Int. J. Biol. Macromol. 163, 9-18. doi:10. 1016/j.ijbiomac.2020.06.173

Emam, H., Leach, D., Sun, Z., Tee, B. C., Karatas, B., Kim, D. G., et al. (2020). The effect of parathyroid hormone analogues when added to mineralized bone xenografts. J. Oral Implantol. 46 (4), 372-379. doi:10.1563/aaid-joi-D-19-00016

Erak, M., Bellmann-Sickert, K., Els-Heindl, S., and Beck-Sickinger, A. G. (2018). Peptide chemistry toolbox - transforming natural peptides into peptide therapeutics. Bioorg. Med. Chem. 26 (10), 2759-2765. doi:10.1016/j.bmc. 2018.01.012

Farooq, I., and Bugshan, A. (2020). The role of salivary contents and modern technologies in the remineralization of dental enamel: a narrative review. F1000Res. 9, 171. doi:10.12688/f1000research.22499.2

Fawzy El-Sayed, K. M., Ahmed, G. M., Abouauf, E. A., and Schwendicke, F. (2019). Stem/progenitor cell-mediated pulpal tissue regeneration: a systematic review and meta-analysis. Int. Endod. J. 52 (11), 1573-1585. doi:10.1111/iej.13177

Fei, Q., Guo, C., Xu, X., Gao, J., Zhang, J., Chen, T., et al. (2010). Osteogenic growth peptide enhances the proliferation of bone marrow mesenchymal stem cells from osteoprotegerin-deficient mice by CDK2/cyclin A. Acta Biochim. Biophys. Sin (Shanghai). 42 (11), 801-806. doi:10.1093/abbs/gmq086

Fermini, B., Coyne, S. T., and Coyne, K. P. (2018). Clinical trials in a dish: a perspective on the coming revolution in drug development. SLAS Discov. 23 (8), 765-776. doi:10.1177/2472555218775028

Fernandes, P. G., Novaes, A. B., Jr., de Queiroz, A. C., de Souza, S. L., Taba, M., Jr., Palioto, D. B., et al. (2011). Ridge preservation with acellular dermal matrix and anorganic bone matrix cell-binding peptide $\mathrm{P}-15$ after tooth extraction in humans. J. Periodontol. 82 (1), 72-79. doi:10.1902/jop.2010.100241

Fosgerau, K., and Hoffmann, T. (2015). Peptide therapeutics: current status and future directions. Drug Discov. Today. 20 (1), 122-128. doi:10.1016/j.drudis. 2014.10.003

Fu, J. H., and Yap, A. U. (2007). Occlusion and periodontal disease--where is the link?. Singapore Dent J. 29 (1), 22-33.

Galler, K. M., Hartgerink, J. D., Cavender, A. C., Schmalz, G., and D’Souza, R. N. (2012). A customized self-assembling peptide hydrogel for dental pulp tissue engineering. Tissue Eng. Part. A. 18 (1-2), 176-184. doi:10.1089/ten.TEA.2011. 0222

Garant, P. R. (2003). Oral cells and tissues. Chicago: Quintessence Pub. Co

Goldberg, M., Kulkarni, A. B., Young, M., and Boskey, A. (2011). Dentin: structure, composition and mineralization. Front Biosci (Elite Ed). 3, 711-735. doi:10. $2741 / \mathrm{e} 281$

Goltzman, D. (2018). Physiology of parathyroid hormone. Endocrinol. Metab. Clin. North. Am. 47 (4), 743-758. doi:10.1016/j.ecl.2018.07.003

González-Cabezas, C., and Fernández, C. E. (2018). Recent advances in remineralization therapies for caries lesions. Adv. Dent Res. 29 (1), 55-59. doi:10.1177/0022034517740124

Grzesik, W. J., Ivanov, B., Robey, F. A., Southerland, J., and Yamauchi, M. (1998). Synthetic integrin-binding peptides promote adhesion and proliferation of human periodontal ligament cells in vitro. J. Dent Res. 77 (8), 1606-1612. doi:10.1177/00220345980770080801

Grzesik, W. J., and Narayanan, A. S. (2002). Cementum and periodontal wound healing and regeneration. Crit. Rev. Oral Biol. Med. 13 (6), 474-484. doi:10. 1177/154411130201300605

Gungormus, M., Horst, J. A., Fong, H., Hnilova, M., Somerman, M. J., Snead, M. L., et al. (2012). Cementomimetics-constructing a cementum-like biomineralized microlayer via amelogenin-derived peptides. Int J Oral Sci. 4 (2), 69-77. doi:10. 1038/ijos.2012.40

Gurtner, G. C., Werner, S., Barrandon, Y., and Longaker, M. T. (2008). Wound repair and regeneration. Nature. 453 (7193), 314-321. doi:10.1038/nature07039

Häkkinen, L., Uitto, V. J., and Larjava, H. (2000). Cell biology of gingival wound healing. Periodontol. 2000. 24 (24), 127-152. doi:10.1034/j.1600-0757.2000. 2240107.x

Hamley, I. W. (2017). Small bioactive peptides for biomaterials design and therapeutics. Chem. Rev. 117 (24), 14015-14041. doi:10.1021/acs.chemrev.7b00522

Han, S., Fan, Y., Zhou, Z., Tu, H., Li, D., Lv, X., et al. (2017). Promotion of enamel caries remineralization by an amelogenin-derived peptide in a rat model. Arch. Oral Biol. 73, 66-71. doi:10.1016/j.archoralbio.2016.09.009

Hara, A. T., and Zero, D. T. (2010). The caries environment: saliva, pellicle, diet, and hard tissue ultrastructure. Dent Clin. North. Am. 54 (3), 455-467. doi:10. 1016/j.cden.2010.03.008

Hassell, T. M. (2000). Tissues and cells of the periodontium. Periodontol. 2000. 3 (3), 9-38. doi:10.1111/j.1600-0757.1993.tb00230.x

Hautanen, A., Gailit, J., Mann, D. M., and Ruoslahti, E. (1989). Effects of modifications of the RGD sequence and its context on recognition by the fibronectin receptor. J. Biol. Chem. 264 (3), 1437-1442. doi:10.1016/s00219258(18)94206-7

Hilton, T. J., Ferracane, J. L., and Mancl, L. (2013). Comparison of $\mathrm{CaOH}$ with MTA for direct pulp capping: a PBRN randomized clinical trial. J. Dent Res. 92 (7 Suppl. 1), 16s-22s. doi:10.1177/0022034513484336

Hsu, C. C., Chung, H. Y., Yang, J. M., Shi, W., and Wu, B. (2011). Influence of 8DSS peptide on nano-mechanical behavior of human enamel. J. Dent Res. 90 (1), 88-92. doi:10.1177/0022034510381904

Huang, B., Sun, Y., Maciejewska, I., Qin, D., Peng, T., McIntyre, B., et al. (2008). Distribution of SIBLING proteins in the organic and inorganic phases of rat dentin and bone. Eur. J. Oral Sci. 116 (2), 104-112. doi:10.1111/j.1600-0722. 2008.00522.x 
Huang, G. T. (2011). Dental pulp and dentin tissue engineering and regeneration: advancement and challenge. Front Biosci (Elite Ed). 3, 788-800. doi:10.2741/ e286

Huang, K. K., Shen, C., Chiang, C. Y., Hsieh, Y. D., and Fu, E. (2005). Effects of bone morphogenetic protein- 6 on periodontal wound healing in a fenestration defect of rats. J. Periodont Res. 40 (1), 1-10. doi:10.1111/j.1600-0765.2004. 00752.x

Huang, Y., Goldberg, M., Le, T., Qiang, R., Warner, D., Witkowska, H. E., et al. (2012). Amelogenin exons 8 and 9 encoded peptide enhances leucine rich amelogenin peptide mediated dental pulp repair. Cells Tissues Organs (Print) 196 (2), 151-160. doi:10.1159/000331248

Ieong, C. C., Zhou, X. D., Li, J. Y., Li, W., and Zhang, L. L. (2011). Possibilities and potential roles of the functional peptides based on enamel matrix proteins in promoting the remineralization of initial enamel caries. Med. Hypotheses 76 (3), 391-394. doi:10.1016/j.mehy.2010.10.050

Jabbari, E. (2013). Osteogenic peptides in bone regeneration. Curr. Pharm. Des. 19 (19), 3391-3402. doi:10.2174/1381612811319190006

Jablonski-Momeni, A., Korbmacher-Steiner, H., Heinzel-Gutenbrunner, M., Jablonski, B., Jaquet, W., and Bottenberg, P. (2019). Randomised in situ clinical trial investigating self-assembling peptide matrix P11-4 in the prevention of artificial caries lesions. Sci. Rep. 9 (1), 269. doi:10.1038/ s41598-018-36536-4

Jung, C., Kim, S., Sun, T., Cho, Y. B., and Song, M. (2019). Pulp-dentin regeneration: current approaches and challenges. J. Tissue Eng. 10, 2041731418819263. doi:10.1177/2041731418819263

Jung, R. E., Cochran, D. L., Domken, O., Seibl, R., Jones, A. A., Buser, D., et al. (2007). The effect of matrix bound parathyroid hormone on bone regeneration. Clin. Oral Implants Res. 18 (3), 319-325. doi:10.1111/j.16000501.2007.01342.x

Kamal, D., Hassanein, H., Elkassas, D., and Hamza, H. (2020). Complementary remineralizing effect of self-assembling peptide (P11-4) with CPP-ACPF or fluoride: an in vitro study. J. Clin. Exp. Dent 12 (2), e161-e168. doi:10.4317/jced. 56295

Kao, R. T., Nares, S., and Reynolds, M. A. (2015). Periodontal regeneration intrabony defects: a systematic review from the AAP Regeneration Workshop. J. Periodontol. 86 (2 Suppl. 1), S77-S104. doi:10.1902/jop.2015.130685

Kato, H., Taguchi, Y., Tominaga, K., Umeda, M., and Tanaka, A. (2013). A synthetic oligopeptide derived from enamel matrix derivative promotes the differentiation of human periodontal ligament stem cells into osteoblast-like cells with increased mineralization. J Periodontol. 84 (10), 1476-83. doi:10.1902/ jop.2012.120469

Kawashima, N., and Okiji, T. (2016). Odontoblasts: specialized hard-tissueforming cells in the dentin-pulp complex. Congenit. Anom. (Kyoto) 56 (4), 144-153. doi:10.1111/cga.12169

Kelly, M. P., Vaughn, O. L., and Anderson, P. A. (2016). Systematic review and meta-analysis of recombinant human bone morphogenetic protein-2 in localized alveolar ridge and maxillary sinus augmentation. J. Oral Maxillofac. Surg. 74 (5), 928-939. doi:10.1016/j.joms.2015.11.027

Khorolsuren, Z., Lang, O., Pallinger, E., Foldes, A., Szabolcs, G. G., Varga, G., et al. (2020). Functional and cell surface characteristics of periodontal ligament cells (PDLCs) on RGD-synthetic polypeptide conjugate coatings. J Periodontal Res. 55 (5), 713-723. doi:10.1111/jre.12760

Kim, M. J., Lee, B., Yang, K., Park, J., Jeon, S., Um, S. H., et al. (2013). BMP-2 peptide-functionalized nanopatterned substrates for enhanced osteogenic differentiation of human mesenchymal stem cells. Biomaterials 34 (30), 7236-7246. doi:10.1016/j.biomaterials.2013.06.019

Kim, S. G. (2017). Biological molecules for the regeneration of the pulp-dentin complex. Dent Clin. North. Amissue. 611, 127-141. doi:10.1016/j.cden.2016. 08.005

Kim, T. I., Jang, J. H., Lee, Y. M., Rhyu, I. C., Chung, C. P., Han, S. B., et al. (2004). Biomimetic approach on human periodontal ligament cells using synthetic oligopeptides. J. Periodontol. 75 (7), 925-932. doi:10.1902/jop. 2004.75.7.925

Kind, L., Stevanovic, S., Wuttig, S., Wimberger, S., Hofer, J., Müller, B., et al. (2017). Biomimetic remineralization of carious lesions by self-assembling peptide. J. Dent Res. 96 (7), 790-797. doi:10.1177/0022034517698419

Kitagawa, M., Kitagawa, S., Nagasaki, A., Miyauchi, M., Uchida, T., and Takata, T. (2011). Synthetic ameloblastin peptide stimulates differentiation of human periodontal ligament cells. Arch. Oral Biol. 56 (4), 374-379. doi:10.1016/j. archoralbio.2010.10.012

Koch, F., Müller, M., König, F., Meyer, N., Gattlen, J., Pieles, U., et al. (2018). Mechanical characteristics of beta sheet-forming peptide hydrogels are dependent on peptide sequence, concentration and buffer composition. $R$ Soc Open Sci. 5 (3), 171562. doi:10.1098/rsos.171562

Lau, J. L., and Dunn, M. K. (2018). Therapeutic peptides: historical perspectives, current development trends, and future directions. Bioorg. Med. Chem. 26 (10), 2700-2707. doi:10.1016/j.bmc.2017.06.052

Lee, D., Park, K. S., Yoon, G. J., Lee, H. J., Lee, J. Y., Park, Y. S., et al. (2019). Identification of cell-penetrating osteogenic peptide from copine-7 protein and its delivery system for enhanced bone formation. J. Biomed. Mater. Res. A. 107 (11), 2392-2402. doi:10.1002/jbm.a.36746

Lee, J. H., Mand, M. R., Deshpande, R. A., Kinoshita, E., Yang, S. H., Wyman, C., et al. (2013). Ataxia telangiectasia-mutated (ATM) kinase activity is regulated by ATP-driven conformational changes in the Mre11/Rad50/ Nbs1 (MRN) complex. J. Biol. Chem. 288 (18), 12840-12851. doi:10.1074/ jbc.M113.460378

Lee, Y. S., Park, Y. H., Lee, D. S., Seo, Y. M., Lee, J. H., Park, J. H., et al. (2020). Tubular dentin regeneration using a CPNE7-derived functional peptide. Materials (Basel). 13 (20),4618. doi:10.3390/ma13204618

Li, J., Volk, R., Gao, Y., Li, M., Metais, C., Sato, K., et al. (2000). PR39, a peptide regulator of angiogenesis. Nat. Med. 6 (1), 49-55. doi:10.1038/71527

Li, Z. C., Qin, X., Ren, Q., Hu, D., Tian, T., He, T., et al. (2020). Rational design of $\beta$-sheet peptides with self-assembly into nanofibres on remineralisation of initial caries lesions. Chin. J. Dent Res. 23 (2), 131-141. doi:10.3290/j.cjdr. a44749

Liang, Y., Luan, X., and Liu, X. (2020). Recent advances in periodontal regeneration: a biomaterial perspective. Bioact Mater. 5 (2), 297-308. doi:10. 1016/j.bioactmat.2020.02.012

Lien, S., and Lowman, H. B. (2003). Therapeutic peptides. Trends Biotechnol. 21 (12), 556-562. doi:10.1016/j.tibtech.2003.10.005

Liu, H., Li, W., Gao, C., Kumagai, Y., Blacher, R. W., and DenBesten, P. K. (2004). Dentonin, a fragment of MEPE, enhanced dental pulp stem cell proliferation. J. Dent Res. 83 (6), 496-499. doi:10.1177/ 154405910408300612

Lv, X., Yang, Y., Han, S., Li, D., Tu, H., Li, W., et al. (2015). Potential of an amelogenin based peptide in promoting reminerlization of initial enamel caries. Arch. Oral Biol. 60 (10), 1482-1487. doi:10.1016/j.archoralbio.2015.07.010

Maeda, Y., Miwa, Y., and Sato, I. (2017). Expression of CGRP, vasculogenesis and osteogenesis associated mRNAs in the developing mouse mandible and tibia. Eur. J. Histochem. 61 (1), 2750. doi:10.4081/ejh.2017.2750

Magda, S. (2010). Teriparatide and bone regeneration in the jaw. Maedica (Buchar) 5 (4), 303

McCulloch, C. A., and Melcher, A. H. (1983). Cell density and cell generation in the periodontal ligament of mice. Am. J. Anat. 167 (1), 43-58. doi:10.1002/aja. 1001670105

McKay, B., and Sandhu, H. S. (2002). Use of recombinant human bone morphogenetic protein-2 in spinal fusion applications. Spine (Phila $\mathrm{Pa}$ 1976). 27, S66-S85. doi:10.1097/00007632-200208151-00014

Michot, B., Casey, S. M., and Gibbs, J. L. (2020). Effects of calcitonin gene-related peptide on dental pulp stem cell viability, proliferation, and differentiation. J. Endod. 46 (7), 950-956. doi:10.1016/j.joen.2020.03.010

Montoya, G., Correa, R., Arenas, J., Hoz, L., Romo, E., Arroyo, R., et al. (2019). Cementum protein 1-derived peptide (CEMP 1-p1) modulates hydroxyapatite crystal formation in vitro. J. Pept. Sci. 25 (10), e3211. doi:10.1002/psc.3211

Montoya, G., Lopez, K., Arenas, J., Zamora, C., Hoz, L., Romo, E., et al. (2020). Nucleation and growth inhibition of biological minerals by cementum attachment protein-derived peptide (CAP-pi). J. Pept. Sci. 26 (12), e3282. doi: $10.1002 /$ psc.3282

Moore, A. N., Perez, S. C., Hartgerink, J. D., D’Souza, R. N., and Colombo, J. S. (2015). Ex Vivo modeling of multidomain peptide hydrogels with intact dental pulp. J. Dent Res. 94 (12), 1773-1781. doi:10.1177/0022034515600380

Moussa, D. G., and Aparicio, C. (2019). Present and future of tissue engineering scaffolds for dentin-pulp complex regeneration. J. Tissue Eng. Regen. Med. 13 (1), 58-75. doi:10.1002/term.2769

Mu, X., Shi, L., Pan, S., He, L., Niu, Y., and Wang, X. (2020). A customized selfassembling peptide hydrogel-wrapped stem cell factor targeting pulp 
regeneration rich in vascular-like structures. ACS Omega. 5 (27), 16568-16574. doi:10.1021/acsomega.0c01266

Mukherjee, K., Ruan, Q., and Moradian-Oldak, J. (2019). Peptide-mediated biomimetic regrowth of human enamel in situ. Methods Mol. Biol. 1922, 129-138. doi:10.1007/978-1-4939-9012-2_13

Nagel, D. E., Khosla, S., Sanyal, A., Rosen, D. M., Kumagai, Y., and Riggs, B. L. (2004). A fragment of the hypophosphatemic factor, MEPE, requires inducible cyclooxygenase-2 to exert potent anabolic effects on normal human marrow osteoblast precursors. J. Cel Biochem 93 (6), 1107-1114. doi: $10.1002 /$ jcb. 20249

Nagy, K., Láng, O., Láng, J., Perczel-Kovách, K., Gyulai-Gaál, S., Kádár, K., et al. (2018). A novel hydrogel scaffold for periodontal ligament stem cells. Interv. Med. Appl. Sci. 10 (3), 162-170. doi:10.1556/1646.10.2018.21

Nanci, A., and Bosshardt, D. D. (2000). Structure of periodontal tissues in health and disease. Periodontol. 200040 (40), 11-28. doi:10.1111/j.1600-0757.2005. 00141. $\mathrm{x}$

Nguyen, P. K., Gao, W., Patel, S. D., Siddiqui, Z., Weiner, S., Shimizu, E., et al. (2018). Self-assembly of a dentinogenic peptide hydrogel. ACS Omega. 3 (6), 5980-5987. doi:10.1021/acsomega.8b00347

Pandya, M., and Diekwisch, T. G. H. (2019). Enamel biomimetics-fiction or future of dentistry. Int. J. Oral Sci. 11 (1), 8. doi:10.1038/s41368-0180038-6

Park, H. J., Salem, M., Semlali, A., Leung, K. P., and Rouabhia, M. (2017). Antimicrobial peptide KSL-W promotes gingival fibroblast healing properties in vitro. Peptides. 93, 33-43. doi:10.1016/j.peptides.2017.05.003

Petzold, C., Monjo, M., Rubert, M., Reinholt, F. P., Gomez-Florit, M., Ramis, J. M., et al. (2013). Effect of proline-rich synthetic peptide-coated titanium implants on bone healing in a rabbit model. Int. J. Oral Maxillofac. Implants 28 (6), e547-55. doi:10.11607/jomi.te35

Pigossi, S. C., Medeiros, M. C., Saska, S., Cirelli, J. A., and Scarel-Caminaga, R. M. (2016). Role of osteogenic growth peptide (OGP) and OGP(10-14) in bone regeneration: a review. Int. J. Mol. Sci. 17 (11), 1885. doi:10.3390/ijms17111885

Piva, E., Silva, A. F., and Nör, J. E. (2014). Functionalized scaffolds to control dental pulp stem cell fate. J. Endod. 40 (4, Suppl. ment), S33-S40. doi:10.1016/j.joen. 2014.01.013

Polimeni, G., Xiropaidis, A. V., and Wikesjö, U. M. (2000). Biology and principles of periodontal wound healing/regeneration. Periodontol. 20002006. 41 (1), 30-47. doi:10.1111/j.1600-0757.2006.00157.x

Pountos, I., Panteli, M., Lampropoulos, A., Jones, E., Calori, G. M., and Giannoudis, P. V. (2016). The role of peptides in bone healing and regeneration: a systematic review. $B M C$ Med. 14, 103. doi:10.1186/s12916016-0646-y

Prajapati, S., Ruan, Q., Mukherjee, K., Nutt, S., and Moradian-Oldak, J. (2018). The presence of MMP-20 reinforces biomimetic enamel regrowth. J. Dent Res. 97 (1), 84-90. doi:10.1177/0022034517728504

Qiao, Y., Liu, X., Zhou, X., Zhang, H., Zhang, W., Xiao, W., et al. (2020). Gelatin templated polypeptide Co-Cross-Linked hydrogel for bone regeneration. Adv. Healthc. Mater. 9 (1), e1901239. doi:10.1002/adhm.201901239

Rahiotis, C., and Vougiouklakis, G. (2007). Effect of a CPP-ACP agent on the demineralization and remineralization of dentine in vitro. J. Dent. 35 (8), 695-698. doi:10.1016/j.jdent.2007.05.008

Ramis, J. M., Rubert, M., Vondrasek, J., Gayà, A., Lyngstadaas, S. P., and Monjo, M. (2012). Effect of enamel matrix derivative and of proline-rich synthetic peptides on the differentiation of human mesenchymal stem cells toward the osteogenic lineage. Tissue Eng. Part. A. 18 (11-12), 1253-1263. doi:10.1089/ten.tea.2011. 0404

Roberts, W. E., Mozsary, P. G., and Klingler, E. (1982). Nuclear size as a cell-kinetic marker for osteoblast differentiation. Am. J. Anat. 165 (4), 373-384. doi:10. 1002/aja.1001650403

Saghiri, M. A., Asatourian, A., Sorenson, C. M., and Sheibani, N. (2015). Role of angiogenesis in endodontics: contributions of stem cells and proangiogenic and antiangiogenic factors to dental pulp regeneration. J. Endod. 41 (6), 797-803. doi:10.1016/j.joen.2014.12.019

Sasaki, T., and Garant, P. R. (1996). Structure and organization of odontoblasts. Anat. Rec. 245 (2), 235-249. doi:10.1002/(SICI)1097-0185(199606)245:2<235:: AID-AR10>3.0.CO;2-Q

Saska, S., Pigossi, S. C., Oliveira, G. J. P. L., Teixeira, L. N., Capela, M. V., Gonçalves, A., et al. (2018). Biopolymer-based membranes associated with osteogenic growth peptide for guided bone regeneration. Biomed. Mater. 13 (3), 035009. doi:10.1088/1748-605X/aaaa2d

Sato, A. K., Viswanathan, M., Kent, R. B., and Wood, C. R. (2006). Therapeutic peptides: technological advances driving peptides into development. Curr. Opin. Biotechnol. 17 (6), 638-642. doi:10.1016/j.copbio.2006.10.002

Sattabanasuk, V., Burrow, M. F., Shimada, Y., and Tagami, J. (2014). Bonding of resin luting cements to dentine after casein phosphopeptide-amorphous calcium phosphate (CPP-ACP) treatment. Int. J. Adhes. Adhesives 54, 93-99. doi:10.1016/j.ijadhadh.2014.05.008

Sculean, A., Gruber, R., and Bosshardt, D. D. (2014). Soft tissue wound healing around teeth and dental implants. J. Clin. Periodontol. 41 (Suppl 15), S6-S22. doi:10.1111/jcpe.12206

Seo, Y. M., Park, S. J., Lee, H. K., and Park, J. C. (2017). Copine-7 binds to the cell surface receptor, nucleolin, and regulates ciliogenesis and Dspp expression during odontoblast differentiation. Sci. Rep. 7 (1), 11283. doi:10.1038/s41598017-11641-y

Seyhan, A. A. (2019). Lost in translation: the valley of death across preclinical and clinical divide - identification of problems and overcoming obstacles. Translational Med. Commun. 4 (1), 18. doi:10.1186/s41231-019-0050-7

Six, N., Septier, D., Chaussain-Miller, C., Blacher, R., DenBesten, P., and Goldberg, M. (2007). Dentonin, a MEPE fragment, initiates pulp-healing response to injury. J. Dent Res. 86 (8), 780-785. doi:10.1177/154405910708600818

Smith, A. J., Cassidy, N., Perry, H., Bègue-Kirn, C., Ruch, J. V., and Lesot, H. (1995). Reactionary dentinogenesis. Int. J. Dev. Biol. 39 (1), 273-280.

Smith, P. C., Cáceres, M., Martínez, C., Oyarzún, A., and Martínez, J. (2015). Gingival wound healing: an essential response disturbed by aging?. J. Dent Res. 94 (3), 395-402. doi:10.1177/0022034514563750

Soldatos, N. K., Stylianou, P., Koidou, V. P., Angelov, N., Yukna, R., and Romanos, G. E. (2017). Limitations and options using resorbable versus nonresorbable membranes for successful guided bone regeneration. Quintessence Int. 48 (2), 131-147. doi:10.3290/j.qi.a37133

Staines, K. A., MacRae, V. E., and Farquharson, C. (2012). The importance of the SIBLING family of proteins on skeletal mineralisation and bone remodelling. J. Endocrinol. 214 (3), 241-255. doi:10.1530/JOE-12-0143

Stürmer, E. (1989). Vasopressin, oxytocin and synthetic analogues: the use of bioassays. J. Pharm. Biomed. Anal. 7 (2), 199-210. doi:10.1016/0731-7085(89) 80084-6

Tanaka, S., Yasuda, T., Hamada, Y., Kawaguchi, N., Fujishita, Y., Mori, S., et al. (2020). Synthetic peptide SVVYGLR upregulates cell motility and facilitates oral mucosal wound healing. Peptides. 134, 170405. doi:10.1016/j.peptides. 2020.170405

Tashjian, A. H., Jr., and Gagel, R. F. (2006). Teriparatide [human PTH(1-34)]: 2.5 years of experience on the use and safety of the drug for the treatment of osteoporosis. J. Bone Miner Res. 21 (3), 354-365. doi:10.1359/JBMR.051023

Tomokiyo, A., Wada, N., and Maeda, H. (2019). Periodontal ligament stem cells: regenerative potency in periodontium.Stem Cells Dev. 28 (15), 974-985. doi:10. 1089/scd.2019.0031

Üstün, N., and Aktören, O. (2019). Analysis of efficacy of the self-assembling peptide-based remineralization agent on artificial enamel lesions. Microsc. Res. Tech. 82 (7), 1065-1072. doi:10.1002/jemt.23254

Valente, M. T., Moffa, E. B., Crosara, K. T. B., Xiao, Y., de Oliveira, T. M., Machado, M. A. A. M., et al. (2018). Acquired enamel pellicle engineered peptides: effects on hydroxyapatite crystal growth. Sci. Rep. 8 (1), 3766. doi:10.1038/s41598-01821854-4

Vastardis, S., Yukna, R. A., Mayer, E. T., and Atkinson, B. L. (2005). Periodontal regeneration with peptide-enhanced anorganic bone matrix in particulate and putty form in dogs. J. Periodontol. 76 (10), 1690-1696. doi:10.1902/jop.2005.76.10.1690

Villa, O., Wohlfahrt, J. C., Mdla, I., Petzold, C., Reseland, J. E., Snead, M. L., et al. (2015). Proline-rich peptide mimics effects of enamel matrix derivative on rat oral mucosa incisional wound healing. J Periodontol. 86 (12), 1386-95. doi:10. 1902/jop.2015.150207

Villegas-Mercado, C. E., Agredano-Moreno, L. T., Bermúdez, M., Segura-Valdez, M. L., Arzate, H., Del Toro-Rangel, E. F., et al. (2018). Cementum protein 1 transfection does not lead to ultrastructural changes in nucleolar organization of human gingival fibroblasts. J. Periodontal Res. 53 (4), 636-642. doi:10.1111/jre.12553

Vlieghe, P., Lisowski, V., Martinez, J., and Khrestchatisky, M. (2010). Synthetic therapeutic peptides: science and market. Drug Discov. Today 15 (1-2), 40-56. doi:10.1016/j.drudis.2009.10.009 
Wang, C., Liu, Y., Fan, Y., and Li, X. (2017). The use of bioactive peptides to modify materials for bone tissue repair. Regen. Biomater. 4 (3), 191-206. doi:10.1093/ $\mathrm{rb} / \mathrm{rbx} 011$

Wang, D., Deng, J., Deng, X., Fang, C., Zhang, X., and Yang, P. (2020). Controlling enamel remineralization by amyloid-like amelogenin mimics. Adv. Mater. 32 (31), e2002080. doi:10.1002/adma.202002080

Wang, X., He, H., Wu, X., Hu, J., and Tan, Y. (2014). Promotion of dentin regeneration via CCN3 modulation on Notch and BMP signaling pathways. Biomaterials 35 (9), 2720-2729. doi:10.1016/j.biomaterials.2013.12.029

Wikesjö, U. M., and Selvig, K. A. (2000). Periodontal wound healing and regeneration. Periodontol. 200019 (19), 21-39.

Xia, K., Chen, Z., Chen, J., Xu, H., Xu, Y., Yang, T., et al. (2020). RGD- and VEGFmimetic peptide epitope-functionalized self-assembling peptide hydrogels promote dentin-pulp complex regeneration. Int. J. Nanomedicine 15, 6631-6647. doi:10.2147/IJN.S253576

Xiao, Z., Que, K., Wang, H., An, R., Chen, Z., Qiu, Z., et al. (2017). Rapid biomimetic remineralization of the demineralized enamel surface using nanoparticles of amorphous calcium phosphate guided by chimaeric peptides. Dent Mater. 33 (11), 1217-1228. doi:10.1016/j.dental.2017.07.015

Yamashita, M., Lazarov, M., Jones, A. A., Mealey, B. L., Mellonig, J. T., and Cochran, D. L. (2010). Periodontal regeneration using an anabolic peptide with two carriers in baboons. J. Periodontol. 81 (5), 727-736. doi:10.1902/jop.2010.090224

Yang, Y., Lv, X., Shi, W., Zhou, X., Li, J., and Zhang, L. (2016). Synergistic inhibition of enamel demineralization by peptide 8DSS and fluoride. Caries Res. 50 (1), 32-39. doi:10.1159/000442896

Yang, Y., Lv, X. P., Shi, W., Li, J. Y., Li, D. X., Zhou, X. D., et al. (2014). 8DSSpromoted remineralization of initial enamel caries in vitro. J. Dent Res. 93 (5), 520-524. doi:10.1177/0022034514522815

Yang, Y., Yang, B., Li, M., Wang, Y., Yang, X., and Li, J. (2017). Salivary acquired pellicle-inspired DpSpSEEKC peptide for the restoration of demineralized tooth enamel. Biomed. Mater. 12 (2), 025007. doi:10.1088/1748-605X/aa5daf

Yarbrough, D. K., Hagerman, E., Eckert, R., He, J., Choi, H., Cao, N., et al. (2010). Specific binding and mineralization of calcified surfaces by small peptides. Calcif Tissue Int. 86 (1), 58-66. doi:10.1007/s00223-009-9312-0

Yen, A. H., and Yelick, P. C. (2011). Dental tissue regeneration - a mini-review. Gerontology. 57, 85-94. doi:10.1159/000314530
Yoshida, S., Tomokiyo, A., Hasegawa, D., Hamano, S., Sugii, H., and Maeda, H. (2020). Insight into the role of dental pulp stem cells in regenerative therapy. Biology (Basel). 9 (7), 160. doi:10.3390/biology9070160

Yukna, R., Salinas, T. J., and Carr, R. F. (2002). Periodontal regeneration following use of ABM/P-1 5: a case report. Int. J. Periodontics Restorative Dent. 22 (2), $146-155$.

Zanetti, M. (2004). Cathelicidins, multifunctional peptides of the innate immunity. J. Leukoc. Biol. 75 (1), 39-48. doi:10.1189/jlb.0403147

Zeichner-David, M., Chen, L. S., Hsu, Z., Reyna, J., Caton, J., and Bringas, P. (2006). Amelogenin and ameloblastin show growth-factor like activity in periodontal ligament cells. Eur. J. Oral Scidiscussion 114 (Suppl 1), 244-253. doi:10.1111/j. 1600-0722.2006.00322.x

Zero, D. T., Zandona, A. F., Vail, M. M., and Spolnik, K. J. (2011). Dental caries and pulpal disease. Dent Clin. North. Am. 55 (1), 29-46. doi:10.1016/j.cden.2010.08.010

Zhang, B., Sun, Y., Chen, L., Guan, C., Guo, L., and Qin, C. (2010). Expression and distribution of SIBLING proteins in the predentin/dentin and mandible of hyp mice. Oral Dis. 16 (5), 453-464. doi:10.1111/j.1601-0825.2010.01656.x

Zhang, W., Wu, S. Z., Zhou, J., Chen, H. M., Gong, Y. L., Peng, F. F., et al. (2017). Parathyroid hormone-related peptide (1-34) reduces alveolar bone loss in type 1 diabetic rats. Arch. Oral Biol. 83, 13-19. doi:10.1016/j.archoralbio.2017.06.013

Zhou, Y., Zhou, Y., Gao, L., Wu, C., and Chang, J. (2018). Synthesis of artificial dental enamel by an elastin-like polypeptide assisted biomimetic approach. J. Mater. Chem. B. 6 (5), 844-853. doi:10.1039/c7tb02576a

Conflict of Interest: The authors declare that the research was conducted in the absence of any commercial or financial relationships that could be construed as a potential conflict of interest.

Copyright (c) 2021 Bermúdez, Hoz, Montoya, Nidome, Pérez-Soria, Romo, SotoBarreras, Garnica-Palazuelos, Aguilar-Medina, Ramos-Payán and VillegasMercado. This is an open-access article distributed under the terms of the Creative Commons Attribution License (CC BY). The use, distribution or reproduction in other forums is permitted, provided the original author(s) and the copyright owner(s) are credited and that the original publication in this journal is cited, in accordance with accepted academic practice. No use, distribution or reproduction is permitted which does not comply with these terms. 